\title{
Relevance of Plant Growth Promoting Microorganisms and Their Derived Compounds, in the Face of Climate Change
}

\author{
Judith Naamala $@$ and Donald L. Smith * \\ Department of Plant Science, McGill University, Lakeshore Road, Ste. Anne de Bellevue, 21111, Montreal, \\ QC H9X3V9, Canada; naamala.judith@mail.mcgill.ca \\ * Correspondence: Donald.Smith@McGill.Ca
}

Received: 29 May 2020; Accepted: 6 August 2020; Published: 12 August 2020

\begin{abstract}
Climate change has already affected food security in many parts of the world, and this situation will worsen if nothing is done to combat it. Unfortunately, agriculture is a meaningful driver of climate change, through greenhouse gas emissions from nitrogen-based fertilizer, methane from animals and animal manure, as well as deforestation to obtain more land for agriculture. Therefore, the global agricultural sector should minimize greenhouse gas emissions in order to slow climate change. The objective of this review is to point out the various ways plant growth promoting microorganisms (PGPM) can be used to enhance crop production amidst climate change challenges, and effects of climate change on more conventional challenges, such as: weeds, pests, pathogens, salinity, drought, etc. Current knowledge regarding microbial inoculant technology is discussed. Pros and cons of single inoculants, microbial consortia and microbial compounds are discussed. A range of microbes and microbe derived compounds that have been reported to enhance plant growth amidst a range of biotic and abiotic stresses, and microbe-based products that are already on the market as agroinputs, are a focus. This review will provide the reader with a clearer understanding of current trends in microbial inoculants and how they can be used to enhance crop production amidst climate change challenges.
\end{abstract}

Keywords: plant growth promoting microorganisms; climate change; abiotic stress; biotic stress

\section{Introduction}

The world is at a point where we can no longer prevent all of the effects of climate change (because some of it is already here), but can only slow its further progress. The purpose of this paper is therefore to give the reader an understanding of why plant growth promoting organisms, or their products, are relevant, amidst climate change challenges, by showing how they can be used to mitigate the effects of climate change on crop production. The paper also highlights the various ways in which this approach can be used, and the role that inoculant formulation plays in maintaining the efficacy, durability and handling of microbial inoculants. The major drivers of climate change are human driven [1-3]. Burning of fossil fuels for energy, agriculture and industrialisation all contribute to emission of greenhouse gases (GHGs), such as: methane, carbon dioxide and nitrous oxide $\left(\mathrm{N}_{2} \mathrm{O}\right)$. Agriculture is a major contributor to greenhouse gas emissions [4,5], especially through the use of $\mathrm{N}$ based fertilizers, methane emissions from animals and animal manure, deforestation to acquire more land for crop production, etc. According to the intergovernmental panel on climate change (IPCC) report on GHG emissions, energy consumption contributes about 35\%, agriculture, forestry and related land use $24 \%$, industry $21 \%$ and transport $14 \%$ [6]. The greenhouse gases then trap heat radiating from the earth's surface, causing global warming. Unfortunately, climate change also adversely affects 
agriculture [6,7], especially because, along with increases in global temperature, comes the increased prevalence of biotic and abiotic stresses that are detrimental to agriculture production, such as: pests, pathogens, nutrient deficiencies, salinity and weather extremes [1,8-10], some of which may encourage the further use of chemicals to correct, while there is little that can be done about others such as high temperatures and floods. Unmanaged, such factors affect plant growth and render arable land unproductive. This puts us in a challenging situation, especially because world population is growing so that there is a need to increase food production [5], both through increasing yield per unit area and reclaiming more land for crop production [11]. Therefore, while we strive hard to hold greenhouse gas emissions to 'bearable' levels, there is also a need for sustainable approaches that will ensure increased food production in the face of climate change. The use of agrochemicals has boosted crop productivity and contributed to food security, especially in developed countries. However, shortcomings related to their improper and continuous use, such as: increased greenhouse gas emissions (which is a major contributor to global warming), surface and ground water contamination, residual contamination of crop harvest, which poses health concerns to both humans and animals, as well as high costs related to their use. These circumstances have created a need for a more ecofriendly and sustainable approach for enhancing crop productivity in the face of climate change [11-13].

Several approaches have been suggested; the use of plant growth promoting microorganisms and compounds that they produce is perhaps the most promising [14]. The holobiont refers to plants and their associated microbes, which probably coexisted since the colonization of land by the first terrestrial plants [15-17]. This association is referred to as the holobiont [18], and it is dynamic, with the plant asserting a great influence on the nature of phytomicrobiome, especially in its rhizosphere [19], which is mainly attributed to the composition of their root exudates. The rhizosphere, endosphere and phyllosphere may be comprised of pathogenic, neutral and beneficial microbes, in relation to the plant $[18,20]$. Microbes that exert beneficial effects on the plant are termed plant growth promoting microorganisms (PGPM). These microbes may inhabit the rhizosphere, rhizoplane, phyllosphere, endosphere, etc. [19] For decades, PGPM such as rhizobia, mycorrhizae and plant growth promoting bacteria (PGPR, first defined by Kloepper and Schroth, in 1978) have been reported to enhance plant growth under stressed and non-stressed conditions. The use of microbial inoculants is an old practice [21] that has recently gained more prominence during the last three decades. Much research has been done on rhizobia, and currently a lot is being done on plant growth promoting rhizobacteria and PGPR derived compounds. The ability of microbes to suppress plant pathogens, as well as mitigate the effect of abiotic stress on plants, has been investigated by many researchers, and the findings are promising.

Although they occur naturally in the rhizosphere, and plant tissue, PGPM populations are often insufficient to induce desired effects, hence, it is recommendable to isolate them from their natural environments and multiply their populations before reintroduction into the soil or onto the plant as microbial inoculants [14]. Products in the form of microbe-produced compounds are currently gaining popularity among researchers, although they are less well known among farmers, in comparison to microbial cell inoculants, packaged as either single microbial strains or consortia, which have been commercialised for quite some time [21,22]. Microbe based inoculants are generally from the bacteria (such as Bacillus and Rhizobia) and fungi (especially Trichordema) subgroups [19,22,23], although some groups of archea have also been reported to enhance plant growth. Microbially produced compounds, such as lipochitooligosaccharides (LCO), as plant growth enhancers, on the other hand, are only gaining attention recently, which may explain their lesser availability on the agro-input market. Figure 1 below summarizes some of the mechanisms PGPM employ to mitigate the effects of biotic and abiotic stress on plants, which are later discussed in detail. 


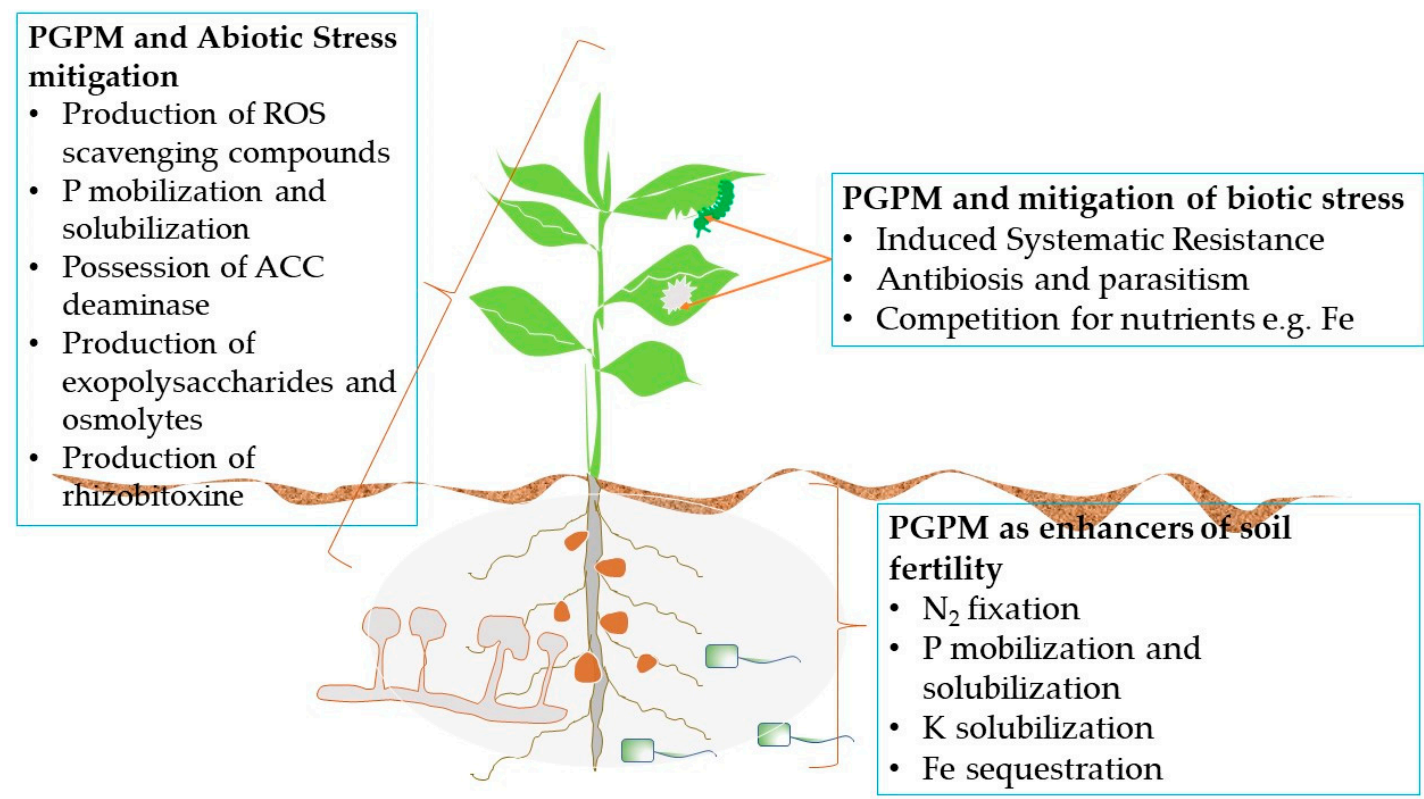

Figure 1. Mechanisms employed by plant growth promoting microorganisms (PGPM) to mitigate effects of biotic and abiotic stress on plants.

\section{PGPM as Enhancers of Soil Fertility}

For proper growth and development, plants need enough supply of essential macro (Nitrogen, Phosphorus, Potasium, Magnesium, Calcium, etc.) and micro (iron, manganese, boron, zinc, molybdenum, copper) nutrients. N, P and $\mathrm{K}$ are the most limiting as far as plant growth is concerned. Unfortunately, with climate change comes abiotic stresses like high temperature, drought and salinity, which influence the biogeochemical transformation of nutrients like $\mathrm{P}, \mathrm{K}$, and $\mathrm{N}$, making them either available or less available for plant uptake [24-26]. While the lack of bioavailable macro and microelements is natural in the soil, it could be worsened by climate change. Nitrogen, phosphorus and potassium as the most plant growth limiting elements and their biogeochemical cycle, are affected by temperature and rainfall amongst other abiotic factors, which happen to be affected by climate change. Processes like decomposition, mineralisation, immobilisation, etc. are largely influenced by temperature and rainfall. Processes like soil erosion should also be noted, which is majorly due to run off and wind affect soil fertility as the nutrient rich topsoil is washed away.

Alkalinity affects the availability of $\mathrm{Fe}, \mathrm{Cu}, \mathrm{Zn}$ and $\mathrm{Mn}$, while very low $\mathrm{pH}$ is associated with $\mathrm{Al}$ toxicity. Processes such as mineralization and nitrogen fixation are affected by moisture, temperature and $\mathrm{pH}$, because they are driven by soil microorganisms like rhizobia, nitrifying bacteria, etc., and enzymes [24,26], which are also affected by abiotic stress. A study by DaMatta et al. [27] showed a decrease in leaf $\mathrm{N}$ content of Coffea canephora due to water stress. For PGPM technology to be relevant, amidst climate change, it is paramount that stress tolerant strains are identified and used. At the same time, the availability of these nutrients is essential, because they play a key role in minimizing the effects of other abiotic stresses like drought, salinity and high temperature on crops. The roles N, P, K, Ca, Mg and Fe play in the mitigation of abiotic stress have been reported by many researchers [27-33]. For instance, $\mathrm{N}$ and $\mathrm{P}$ have been reported to minimize the effects of drought stress $[24-26,34,35]$. K plays a major role in drought stress as well, since it is involved in the opening and closing of the stomata. Agricultural soils have been degraded due to continuous and intense cropping. Agricultural practices like continuous cropping, especially monocropping of non-leguminous crops, without application of fertiliser, is one way of depleting soils of nutrients [36]. This is a common practice of many smallholder farmers, especially in sub-Saharan Africa, due to the inaccessibility and cost of fertiliser [37]. Climate change is only further degrading the situation, because factors such as high temperatures, drought, flooding, salinity, extreme $\mathrm{pH}$, etc. may cause changes in the physiochemical 
properties of essential soil nutrients such as $\mathrm{N}, \mathrm{Fe}, \mathrm{P}$ and $\mathrm{K}$, thereby limiting their mobility and/or affect their availability for plant uptake, while enhancing the accumulation of toxic elements such as aluminum $\left(\mathrm{Al}^{3+}\right)$. The role of stress tolerant beneficial microbes in maintaining/increasing crop production amidst climate change challenges cannot be ignored. In order to reclaim land that has been abandoned due to inadequate nutrients for crop growth, considering the financial and environmental costs related to synthetic fertilisers, stress tolerant plant growth promoting organisms can be a cheaper and sustainable approach. With the need to reclaim more land for crop production, emphasis on enhancing soil fertility is inevitable, because nutrients can enhance plant tolerance to abiotic stress. Therefore, there is a need to address the issue using more sustainable approaches. With limited alternatives, and research output so far, microbial inoculants are a promising approach to enhance soil fertility, particularly in conjunction with the various challenges associated with climate change. Microbial inoculants may be defined as formulations comprised of microorganisms, such as bacteria and fungi, as the active ingredients, which once applied on plants, can enhance their growth $[19,22,38]$. They may also enhance plant quality through the increased concentration of essential nutrients such as proteins [14], and valuable metabolites such as flavonoids, phenolics, alkaloids and carotenoids [23]. Microbial inoculants may also enhance soil biodiversity and properties such as soil structure [22]. As biofertilizers, microbial inoculants enhance the availability and uptake of essential plant nutrients, such as: nitrogen, phosphorus, iron, zinc, and potassium [11-13], which, if lacking or available in inadequate quantities, could limit plant growth.

\subsection{Nitrogen Fixation}

Some free-living and symbiotic bacteria fix atmospheric dinitrogen into plant usable forms, initially ammonium, through biological nitrogen fixation. Symbionts such as Rhizobia, Bradyrhizobium, Sinorhizobium, Frankia, Actinobacteria and Bukholderia form specialized structures called nodules on their host plants, where they obtain nourishment and shelter, and in turn, fix nitrogen [38,39]. The process is referred to as symbiotic nitrogen fixation and it occurs in both legumes and non-leguminous plants, although that of legumes is the most studied. Communication in the form of molecular signals from both the microbe and host plant, as well as a complex of enzymes (e.g., nitrogenase) and genes (nif and/or symbiotic genes), are involved in the process of nitrogen fixation. On the other hand, free-living nitrogen fixing bacteria such as Azotobacter do not need to occupy plant tissue to fix nitrogen. Because of its high energy requirement, plants tend to prefer applied $\mathrm{N}$ fertilizer to biological nitrogen fixation (BNF), hence, for effectiveness, synthetic $\mathrm{N}$ should not be used along with biological nitrogen fixing organisms, because the plant may suppress the nitrogen fixing symbiosis. Where a starter dose of synthetic $\mathrm{N}$ is necessary, it should be applied cautiously, because high $\mathrm{N}$ supply can have an inhibitory effect on nodulation (nodule dry weight and number of nodules) and nitrogenase activity $[24,40,41]$. Arbuscular mycorrhizal fungi, through their hyphae, can enhance the acquisition of soil $\mathrm{N}$ by the plant [42], although there are wide variabilities as to the degree of this, whose causes are not yet known [22]. The efficiency and effectiveness of nitrogen fixing bacteria varies among and within plant species, and, in the agricultural context, are largely limited to members of the fabaceae family. Other crops can benefit from the symbiosis by including legumes in crop rotation regimes. There is also a need for more research on how to extend such modifications to non-leguminous plants. Approaches such as genetic engineering to enable non-legume nitrogen fixation and enhance effective communication with $\mathrm{N}$ fixing microorganisms can be further researched. Although genetic engineering is questionable, especially its ecological impact, some of the questions are likely from a lack of adequate information on the technology. Extensive research to address most of the questions can be very helpful.

\subsection{Phosphate Mobilisation and Solubilisation}

Although phosphorus is an abundant element in most soils, it frequently occurs in forms unavailable for plant use. The application of external sources of $P$ fertiliser, such as single super phosphate, diammonium phosphate, etc., can help meet plants' $\mathrm{P}$ requirements, but this too may be 
immobilised shortly after application, making it largely unavailable for plant uptake [43]. mobilization (chemical solubilization and mineralization), which results in plant available forms of the respective nutrients and solubilization, which is a more general term and does not necessarily result in readily plant available forms. For instance, the solubilization of organic $P$ does not necessarily mean that the $P$ is already plant available, as it may still be bound in unavailable organic forms (e.g., phytates). PGPM may enhance soil phosphorus availability for plant uptake through solubilisation and/or mobilisation of inorganic phosphorus. A PGPM may possess both or either mechanisms. The terms, phosphorus solubilisation and phosphorus mobilisation are often used synonymously by many researchers, although they are not necessarily the same thing. P solubilisation is the broader term, which may entail P mobilisation. Goldstein and Krishnaraj [44] described phosphate solubilising microorganisms as those that convert sparing soluble organic or mineral $\mathrm{P}$, into soluble orthophosphate, in a way that significantly increases $\mathrm{P}$ availability to a specific plant or plant population within the microorganism's native soil ecosystem. The same author defined phosphate mobilising microorganisms as those that convert sparingly soluble organic or mineral $\mathrm{P}$, into soluble orthophosphate $\mathrm{P}$, in a way that significantly contributes to pool of available orthophosphate $(\mathrm{Pi})$ in the native soil ecosystem. Phosphorus solubilising bacteria, such as: Pseudomonas, Bacillus, Burkholderia and Rhizobium, and some fungal species solubilise inorganic phosphates from sparingly soluble forms such as: tricalcium phosphate, dicalcium phosphate and aluminum phosphate, to forms such as hydrogen phosphate $\left(\mathrm{HPO}_{4}{ }^{-2}\right)$, or dihydrogen phosphate $\left(\mathrm{H}_{2} \mathrm{PO}_{4}{ }^{-1}\right)$, which plants can utilise [37,42-46] through the production of low molecular weight organic acid anions, such as gluconate, lactate, glycolate and oxalate. Phosphorus mobilisers, on the other hand, produce enzymes (such as phosphatase, phytase and phosphonoacetate hydrolase) that chelate cations, bind phosphates and dephosphorylate organic phosphates [22,24]. Dephosphorylation is catalyzed by hydrolase enzymes such as phosphonoacetate, which some PGPM can produce. For instance, ectomycorrhiza and ericoid mycorrhizal fungi produce extracellular acid phosphatases and phytases, which catalyse the mineralisation of $P$ from organic complexes in the soil [42,47]. Other fungal species, such as Aspergillus niger, also produce organic acids which aid the process of $\mathrm{P}$ solubilisation $[48,49]$. Through the possession of hyphae, some mycorrhizae such as arbuscular mycorrhizae can deliver up to $80 \%$ of the phosphorus taken up by the host plant $[27,40]$.

\subsection{Sequestering of Iron}

Some PGPM, like Pseudomonas fluorescens and Rhizobia meliloti, sequester iron through the production of siderophores, which can be grouped into four, namely: hydroxamates, catecholates, carboxylates and pyoverdines [50]. Currently, about 500 siderophores have been reported by researchers. Although plants cannot absorb $\mathrm{Fe}^{3+}$, siderophores have a high affinity for $\mathrm{Fe}^{3+}$, which results in an iron-siderophore complex that is then absorbed by plants [51], into their tissues, hence, aiding plants in meeting their iron requirements [14,17,43,52]. In 2013, study findings of Radzki et al. [53] showed an increase in iron content at 12 weeks for iron deficient tomato plants, following inoculation of siderophore producing bacteria, evidence that microbial siderophores can be a source of iron for plants. A study by Sharma and Johri [54] also showed an increase in maize plant growth following inoculation with siderophore producing PGPR. The uptake of Fe-microbial siderophore complexes by strategy II plants, via ligand exchange, between ferrated microbes and a phyto siderophore, was also reported by Yehuda et al. [55] It should also be noted that some plant species can also produce siderophores which bind $\mathrm{Fe}^{3+}$, to form a complex that can be taken up by the plant with the aid of ligands. Production of siderophores is also a benefit in the context of biocontrol in a sense that potential plant pathogens, especially fungal pathogens, are outcompeted for iron sources, which may lead to their death, or ineffectiveness. 


\subsection{Potassium Solubilisation}

Microbes such as: Arthrobacter sp. Bacillus edaphicus, Bacillus circulans and Bacillus mucilaginosus convert sparingly soluble and mineral potassium to soluble forms available for plant use [56]. Through the release of $\mathrm{H}^{+}$and organic anions, such as citrate, malate and oxalate, arbuscular mycorrhiza can also increase the solubility of mineral K [57], thereby increasing the availability of potassium anions for plant uptake, although the increase in $\mathrm{K}^{+}$availability is sometimes related to the increase in phosphorus availability $[22,58]$.

Some PGPR can also directly influence plant growth through the production of phytohormones such as auxins and gibberellins, which enhance plant growth when plant phytohormones are at suboptimal concentrations [37]. They may also produce enzymes which regulate hormone concentration in plant tissue. For instance, some plant growth promoting microorganisms can produce an enzyme, ACC deaminase, which breaks down ACC, a precursor of ethylene, into an alpha keto butyrate and ammonium, hence lowering ethylene concentration in plant tissues [56,59-62]. With more research and proper manipulation, PGPM, with the ability to enhance plant growth, may not necessarily fully replace chemical fertilizer, but lower their use, directly and indirectly, through increasing the plants' nutrient uptake efficiency from applied chemical fertilizers [63]. Manipulations such as developing an effective consortium of microbes that are able to make available key elements in the soil would greatly reduce the need to use chemical fertilizers. For instance, rhizobial species require iron for good growth, and in their nitrogenase complex, hence co-inoculation of rhizobia and siderophore producing PGPM could enhance nodulation and nitrogen fixation [64]. Use of biofertilizers can lower the need to burn fossil fuels for fertilizer production, and the associated contribution to greenhouse gas emissions.

\section{PGPM and Control of Plant Pests and Diseases}

With global warming comes new species of pests, weeds and pathogens currently prevalent in warmer environments. The use of chemicals to suppress such plant growth inhibitors is effective but with negative outcomes related to improper use, cost, and increasing evolution of tolerance to the chemical. The antagonist properties of biocontrols against such plant growth suppressors have been reported by many researchers, and the results are promising. A diversity of PGPM with biocontrol properties has been identified by researchers, conferring benefits to a variety of crop species [65-73]. Berendsen [74] showed that plants, when exposed to pathogen attack, can recruit specific plant growth promoting microbes with biocontrol activity, against the pathogen in question. It is believed that manipulating plant recruited PGPM for inoculant production could be more effective in controlling targeted pathogens, than PGPM isolated from places with no pathogen attack. Biocontrols have the potential to minimise the use of industrially manufactured chemicals in agricultural production. This would mean a decline in burning of fossil fuels, and hence a reduction in greenhouse gas emissions. This is because some pesticides are synthesized in laboratories using hydrocarbons like petroleum, which is a fossil fuel. Reduction in their use can mean a reduction in burning fossil fuels, hence less $\mathrm{CO}_{2}$ emission to the atmosphere. It would also reduce effects on non-targeted members in the ecosystems, which are sometimes affected by chemical use.

Biocontrols may act directly to inhibit growth of biotic agents through hyper parasitism and production of bioactive substances, such as: antibiotics, hydrogen cyanide and phenazines [73], or indirectly through competition for nutrients and active sites on plants, as well as inducing the plant's systemic resistance against the harmful biotic factor [22,38]. Siderophore producing PGPM tend to outcompete other microorganisms for iron sources, which causes inefficiencies in terms of pathogen activities, especially for fungal pathogens, which eventually leads to their death [64]. Induced systemic resistance is triggered by microbe associated molecular patterns (MAMPS), such as lipopolysaccharides, that plants recognise and respond to by turning on their defence systems [75]. Since MAMPS differ among PGPM, it is believed that microbial consortia made up of more than one microbe may induce stronger systemic resistance than single strains [72], although further research needs to be done for a clearer understanding of this potential. PGPM can not only mitigate crop, but also suppress crop 
pests, such as spidermites [76], moths [77], aphids [78], nematodes [67,79], leaffolder pest [80] and cutworms [81], which greatly contribute to losses incurred in crop production, right from planting to harvesting and storage, if not managed well. PGPR control pests through mechanisms such as production of volatile compounds, such as compounds such as $\beta$-ocimene and $\beta$-caryophyllene [76], that attract natural enemies of the pest in question. For example, a study by Pangesti et al. [77] showed an increase in the concentration of parasitoid Microplitis mediator, a natural predator of Mamestra brassicae following the inoculation of Arabidopsis thaliana roots with the rhizobacterium Pseudomonas fluorescens WCS417r. Other mechanisms through which PGPM mitigate the effects of pests include, increased activity of antioxidant enzymes and increased content of proteins and phenolics in plants, etc. In other cases, the biocontrol agent may not have an effect on the biotic antagonist, but will enhance plant yield in the presence of the antagonist [78]. This particular strategy seems very useful, especially in cases where biotic stress factors such as weeds and pests become resistant or unresponsive to other control strategies. It may also enhance/preserve species diversity, hence maintaining ecosystem functionality.

Some PGPM are efficient against pathogens as single strains, while others perform better as a consortium. Details of single strains vs. consortia are discussed later in this review. Table 1 lists PGPM with potential biocontrol activities against the pathogens of various crop species. With the increasing campaign against the use of chemicals, as a means of combating climate change, such strains are a promising substitute for chemicals that are currently prevalent in agricultural production. Currently, the global biocontrol market is approximately 2 billion USD [79], and is expected to grow further. More research on existing microbial species or microbe-produced compounds with biocontrol properties is still desirable, as is the identification of new ones.

Table 1. Biocontrol species against biotic stressors of different crop species.

\begin{tabular}{|c|c|c|c|}
\hline PGPM & Biotic Stress & Host Plant & Reference \\
\hline Bacillus amyloliquefaciens $L Y-1$ & Peronophythora litchii & $\begin{array}{l}\text { Litchi (Litchi chinensis } \\
\text { Sonn.) }\end{array}$ & [71] \\
\hline Burkholderia cepacia & Fusarium oxysporum & Solanum tuberosum & [65] \\
\hline Pseudomonas fluorescens & Fusarium graminearum & $\begin{array}{c}\text { Triticum aestivum(wheat) } \\
\text { cv. Tabuki }\end{array}$ & [66] \\
\hline Pseudomonas fluorescens $\mathrm{CHAO}$ & $\begin{array}{c}\text { Gaeumannomyces graminis } \\
\text { var. tritici }\end{array}$ & Triticum sp. & [64] \\
\hline Pseudomonas fluorescens $\mathrm{CHAO}$ & Thielaviopsis basicola & Nicotiana tabacum & [64] \\
\hline Bacillus spp. & Heterodera glycines & Glycine max. & [82] \\
\hline Serratia proteamaculans & Meloidogyne incognita & Solanum lycopersicum L. & [72] \\
\hline Bacillus aryabhattai A08 & Meloidogyne incognita & Solanum lycopersicum L. & [83] \\
\hline Serratia plymuthica HRO-C48 & Botrytis cinerea & - & [84] \\
\hline $\begin{array}{c}\text { Serratia plymuthica strain C-1, } \\
\text { Chromobacterium sp. strain C-61 and } \\
\text { Lysobacter enzymogenes strain C-3 consortium }\end{array}$ & Phytophthora capsici & Cupsicum spp. & [85] \\
\hline Paenibacillus sp. $300+$ Streptomyces sp. 385 & $\begin{array}{l}\text { Oxysporum } f . \text { sp. } \\
\text { Cucumerinum }\end{array}$ & Cucumis sativus & [86] \\
\hline Pseudomonas fluorescens WCS 358 & $\begin{array}{c}\text { Fusarium oxysporum } f \text { sp. } \\
\text { Raphani }\end{array}$ & Raphanus sativus & [87] \\
\hline Pseudomonas fluorescens & Macrophomina phseolina & Coleus forskohlii Briq. & [68] \\
\hline Pseudomonas aeruginosa 7 NSK2 & Pythium splendens & Lycopersicon esculentum & [88] \\
\hline Pseudomonas fluorescens & Pythium spp. & Triticum sp. & [64] \\
\hline Pseudomonas fluorescens & Pythium ultimum & Gossypium sp. & [64] \\
\hline Bradyrhizobium japonicum NCIM 2746 & $\begin{array}{l}\text { Rhizopus sp. and, } \\
\text { Fusarium sp. }\end{array}$ & Glycine max L. & [89] \\
\hline Paenibacillus lentimorbus B30488 & Scelerotium rolfsii & Solunum lycopersicum L. & [69] \\
\hline
\end{tabular}


Table 1. Cont.

\begin{tabular}{|c|c|c|c|}
\hline PGPM & Biotic Stress & Host Plant & Reference \\
\hline Pseudomonas putida UW4 & Agrobacterium tumefaciens & Solanum lycopersicum & [90] \\
\hline Burkholderia phytofirmans PsJN & Agrobacterium tumefaciens & Solanum lycopersicum & [90] \\
\hline $\begin{array}{c}\text { Bacillus cereus PX35, Bacillus subtilis SM21 } \\
\text { and Serrati asp. XY2 }\end{array}$ & Meloidogyne incognito & S. lycopersicum & [91] \\
\hline Pseudomonas fluorescens strain S35 & Phytophthora infestans & Solanum tuberosum & [73] \\
\hline $\begin{array}{l}\text { Pseudomonas frederiksbergensis strain } 49 \text { and } \\
\text { Pseudomonas fluorescens strain } 19 \text { consortium }\end{array}$ & Phytophthora infestans & Solanum tuberosum & [73] \\
\hline Pseudomonas putida strain R32 & Phytophthora infestans & Solanum tuberosum & [73] \\
\hline Pseudomonas chlororaphis spp. strain $R 47$ & Phytophthora infestans & Solanum tuberosum & [73] \\
\hline Pseudomonas spp. strain $S 49$ & Phytophthora infestans & Solanum tuberosum & [73] \\
\hline Bacillus and Pseudomonas spp. consortium & $\begin{array}{l}\text { Fusarium oxysporum U3 } \\
\text { and Alternaria sp. U10 }\end{array}$ & Nicotiana attenuata & [92] \\
\hline $\begin{array}{l}\text { Chaetomium sp. C72 and Oidodendron sp. Oi3 } \\
\text { consortium }\end{array}$ & $\begin{array}{l}\text { Fusarium oxysporum U3 } \\
\text { and Alternaria sp. U10 }\end{array}$ & Nicotiana attenuata & [92] \\
\hline Pseudomonas chlororaphis R47 & Phytophthora infestans & Solanum tuberosum & {$[69,93]$} \\
\hline Pseudomonas fluorescens strain LBUM 636 & Phytophthora infestans & Solanum tuberosum & [94] \\
\hline Agrobacterium radiobacter var radiobacter & Crown gall & Solunum lycopersicon & [95] \\
\hline Tricoderma koningiopsis Th003 WP & Fusarium oxysporum & Physalis peruviana & [67] \\
\hline $\begin{array}{l}\text { Trichoderma harzianum } \operatorname{Tr} 6+\text { Pseudomonas sp. } \\
\text { Ps14 }\end{array}$ & $\begin{array}{l}\text { Fusarium oxysporum } f . \text { sp. } \\
\text { radicis cucumerinum }\end{array}$ & Cucumis sativus & [96] \\
\hline Pseudomonas sp. Ps14 & Botrytis cinerea & Arabidopsis thaliana & [96] \\
\hline Trichoderma harzianum $\operatorname{Tr} 6$ & Botrytis cinerea & Arabidopsis thaliana & [96] \\
\hline Pseudomonas putida & Spodoptera litura & Solanum lycopersicum L. & [96] \\
\hline $\begin{array}{l}\text { Pseudomnas flourescences Pf1, Bacillus subtilis } \\
\text { Bs and Trichoderma viridae Tv consortium }\end{array}$ & Lasiodiplodia theobromae & Polianthes tuberosa L. & [97] \\
\hline Pseudomonas sp. $23 \mathrm{~S}$ & Clavibacter michiganensis & Solanum lycopersicum L. & [98] \\
\hline Peanibacillus lentimorbus B-30488 & cucumber mosaic virus & $\begin{array}{l}\text { Nicotiana tabacum co } \\
\text { White burley }\end{array}$ & [99] \\
\hline Serratia liquefaciens MG1 & Alternaria alternate & Solanum lycopersicum & [100] \\
\hline $\begin{array}{l}\text { Xanthomonas sp. WCS2014-23, } \\
\text { Stenotrophomonas sp. WCS2014-113 and } \\
\text { Microbacterium sp. WCS2014-259 }\end{array}$ & $\begin{array}{l}\text { Hyaloperonospora } \\
\text { arabidopsidis }\end{array}$ & Arabidopsis thaliana & [74] \\
\hline $\begin{array}{l}\text { Lactobacillus plantarum SLG17 and Bacillus } \\
\text { amyloliquefaciens FLN13 }\end{array}$ & Fusarium spp. & Triticum durum & [101] \\
\hline Fusarium oxysporum strain Fo162 & Aphis gossypii Glover & Cucurbita pepo & [102] \\
\hline Rhizobium etli strain G12 & Aphis gossypii Glover & Cucurbita pepo & [102] \\
\hline Bacillus subtilis strain BEB-DN & Bemisia tabaci & Solanum lycopersicum & [103] \\
\hline Bacillus amyloliquefaciens (SN13) & Rhizoctonia solani & Rice (Oryza sativa) & [104] \\
\hline $\begin{array}{c}\text { Pseudomonas fluorescens Migula strains Pf1 } \\
\text { and AH1 }\end{array}$ & Desmia funeralis & Oryza sativa & [80] \\
\hline Pseudomonas putida and Rothia sp. & Spodoptera litura & Solanum lycopersicum & [81] \\
\hline
\end{tabular}

\section{PGPM and Abiotic Stress}

With climate change, the occurrence of extreme abiotic stresses, such as floods, salinity, high temperature and drought are expected to increase [3,8-10,105]. In fact, much of this is already being experienced in some parts of the world. Winters are becoming warmer in some regions; rainfall is becoming scarcer and more erratic, causing droughts and desertification $[1,2,104]$ in other regions. 
With less rainfall, salinity is more likely to occur, either through irrigation or natural causes [106-111]. All these factors affect crop production, and their management inputs are sufficiently costly that many farmers may not be able to afford them. Factors such as high temperatures can generally not be managed under field conditions. Therefore, there is the need for a strategy that is ecofriendly and manageable by the majority of crop producers. PGPM have been reported to mitigate effects of abiotic stress on plants, hence, allowing the plant to grow and yield relatively well under stress conditions [112-115]. Various researchers have reported the ability of a wide range of PGPM to enhance plant growth, in the presence of abiotic stressors, such as salinity [116,117], drought $[114,118,119]$, heavy metals and acidity. In fact, the ability of some PGPMs to enhance plant growth is only triggered in the presence of stress [118]. They employ mechanisms such as the production of ROS scavenging compounds, possession of ACC deaminase (an enzyme that lowers ethylene concentration in plants exposed to stress), and the production of exopolysaccharides and osmolytes. For example, Akhtar et al. [120] observed an increase in the antioxidant activity of catalase (CAT) in the roots of drought stressed maize plants treated with Bacillus licheniformis (FMCH001). Treated plants also exhibited a higher dry weight and higher water use efficiency. Yang et al. [121] also reported the increased activity of catalase and dehydroascobate reductase enzymes in salinity stressed Quinoa plants treated with an endophytic bacterium known as Burkholderia Phytofirmans PsJN, compared to the untreated plants. The former also exhibited a higher shoot biomass, grain weight and grain yield compared to the latter. Some rhizobia spp. produce the compound rhizobitoxine, which inhibits the activity of ACC synthetase, hence lowering ethylene activity that would otherwise inhibit nitrogen fixation. A PGPM may possess one or more of these mechanisms, all of which act to help a plant thrive under stress conditions. Like plants, PGPM can also be affected by abiotic stress, such as salinity, high temperature and drought, which can lower their efficacy in promoting plant growth, or even death of the microbe, in cases of prolonged exposure to extremes of such conditions [122]. Therefore, it is essential that the strains chosen for use are tolerant to the abiotic stress, whose effect in plants they tend to mitigate. Strains isolated from areas affected by abiotic stress may have an edge over those isolated under normal conditions, although this may not always be the case. The use of microbial consortia may be helpful, especially in areas where more than one factor inhibits crop growth (which is almost always the case under field conditions). However, more research needs to be conducted, for the better deployment of PGPM technology. The exploitation of such microbes has a definite potential to maintain crop production amidst increasing abiotic stresses that are rendering some currently arable land unfit for crop production. Table 2, below, shows some PGPM strains that have been discovered and characterized by researchers, with the potential to mitigate the effects of abiotic stress on a range of plant species.

Table 2. Examples of PGPM that enable plants to withstand abiotic stress.

\begin{tabular}{cccc}
\hline PGPM & Abiotic Stress & Host Plant & Reference \\
\hline Pseudomonas putida MTCC5279 & Drought & chickpea (Cicer arietinum) & {$[114]$} \\
\hline Pseudomonas fluorescens REN1 & Flooding & Rice (Oryza sativa) & {$[123]$} \\
\hline Variovorax paradoxus 5C-2, & Salinity & Peas & {$[115]$} \\
\hline Bacillus amyloliquefaciens SQR9 & salinity & Maize & {$[112]$} \\
\hline Dietzia natronolimnaea & Salinity & Wheat (Triticum aestivum) & {$[116]$} \\
\hline Serratia nematodiphila & Low temperature & pepper (Capsicum annum) & {$[124]$} \\
\hline Burkholderia phytofirmans PsJN & Low temperature & grapevine (Vitis vinifera) & {$[125]$} \\
\hline Pseudomonas vancouverensis & Low temperature & $\begin{array}{c}\text { Tomato (Solanum } \\
\text { lycopersicum) }\end{array}$ & {$[113]$} \\
\hline Pseudomonas sp. S1 & drought & Capsicum annum & {$[118]$} \\
\hline
\end{tabular}


Table 2. Cont.

\begin{tabular}{|c|c|c|c|}
\hline PGPM & Abiotic Stress & Host Plant & Reference \\
\hline Pseudomonas sp. S1 & drought & Vitis vinifera & [118] \\
\hline Achromobacter xylosoxidans & Flooding stress & Ocimumsanctum & [126] \\
\hline $\begin{array}{c}\text { Pseudomonas sp. } 54 \mathrm{RB}+\text { Rhizobium sp. } \\
\text { Thal-8 }\end{array}$ & Salinity & Zea mays cv. Agaiti 2002 & [127] \\
\hline $\begin{array}{l}\text { Pseudomonas putida KT2440, } \\
\text { Sphingomonas sp. OF178, Azospirillum } \\
\text { brasilense Sp7 and Acinetobacter sp. } \\
\text { EMM02) consortium }\end{array}$ & drought & Zea mays & [119] \\
\hline Achromobacter xylosoxidans & salinity & Catharanthus roseus & [128] \\
\hline Burkholdera cepacia SE4 & salinity & Cucumis sativus L. & [124] \\
\hline Pseudomonas putida (W2) & salinity & Triticum aestivum $\mathrm{L}$. & [56] \\
\hline Pseudomonas fluorescens (W17) & salinity & Triticum aestivum $\mathrm{L}$. & [56] \\
\hline Kocuria flava AB402 & Arsenic toxicity & Oryza sativum & [129] \\
\hline Bacillus vietnamensis $A B 403$ & Arsenic toxicity & Oryza sativum & [129] \\
\hline Trichoderma spp. strain, M-35 & Arsenic toxicity & Cicer arietinum & [130] \\
\hline $\begin{array}{l}\text { Burkholderia cepacia and Penicillium } \\
\text { chrysogenum consortium }\end{array}$ & waste motor oil toxicity & Sorghum bicolor & [131] \\
\hline Bacillus safensis & High temperature & Triticum aestivum $L$. & [132] \\
\hline Pseudomonas aeruginosa & Zn-induced oxidative stress & Triticum aestivum $L$. & [133] \\
\hline $\begin{array}{l}\text { Bacillus licheniformis } \\
\text { (FMCH001) }\end{array}$ & $\begin{array}{c}\text { oxidative stress } \\
\text { Drought }\end{array}$ & Zea mays L.cv. Ronaldinho & [120] \\
\hline Burkholderia phytofirmans PsJN & Salinity & Chenopodium quinoa Willd & [121] \\
\hline
\end{tabular}

\section{Commercialisation of Microbial Inoculants}

Making PGPM technology available for farmers is key to ensuring their adaptation as agricultural inputs. Commercialisation of promising strains is one way of making promising strains accessible by farmers. Although various strains that possess desirable properties under laboratory and greenhouse conditions may be isolated, developing a commercial product, effective under field conditions, is not an easy task, especially because numerous factors determine the efficiency of introduced species. Characteristics such as: possession of multiple mechanisms of enhancing plant growth, ability to compete favorably and establish populations in the rhizosphere, persistence in the rhizosphere over seasons, and ability to be cultured in artificial environments $[15,61,89]$ are desired for potential PGPM strains. However, many plant and soil factors, such as plant species, soil temperature, composition and prevalence of native microbes, soil $\mathrm{pH}$, etc., may work together against a strain which is otherwise excellent under controlled environment conditions. Even before introduction into the field, factors such as formulation play a major part concerning a product's efficacy. For instance, solid inoculant formulations are desired for their longer shelf life, however, the process of drying microbes often results in lower microbial cell counts, hence lowering their competitiveness, since number contributes greatly to their ability to compete with native microbes [134]. Exposing a potential PGPM to some level of stress before formulation may increase its survival rates during formulation and after field application [134]. Before introducing a potential PGPM inoculant into the market, a series of events, such as greenhouse and field trials, characterization, toxicology profiling, etc. occur, most of which are intended to increase strain survival and efficacy in the field. 


\section{Formulation of Microbial Inoculants for Commercial Purposes and Their Mode of Application}

Microbial inoculants are usually a combination of microbial cells and/or their parts/compounds and a nonliving carrier that may be in form of a liquid or solid material $[15,24,38]$. Microbial cells may be either active or dormant; in the latter case, they have to be activated before or after inoculation [15]. They may also be pure cultures (single strains) or a combination of microbial strains (microbial consortia) $[15,38]$. Formulation is a major contributor to the variation in performance of inoculants observed in farmers' fields and at research stations. Formulation can shield the microbe from adverse environmental conditions, increase their shelf life and also supply their nutritional requirements, hence enhancing their chances of survival in the field [23,134]. Normally, a group of microbes are isolated from their natural habitat (soil or plant tissue), tested for their ability to promote plant growth under a range of conditions, and the superior strains are selected for commercialisation purposes. The strains are multiplied and formulated under controlled environment conditions, after which the efficiency of the inoculant is evaluated under field conditions [23]. The method of formulation ought to consider the target crop, target market and mode of application, the latter because the type of formulation often dictates the mode of application of the inoculant. For instance, solid formulations are mainly applied through seed dressing, or broadcasting onto the field, while liquid formulations have a wide range of application methods $[15,24,38]$. Liquid carriers are mostly water and/or organic solvents (other than microbial media), such as glycerol and carboxymethyl cellulose that are added to increase properties such as stickiness and dispersal abilities [23]. There are several types of solid carriers, such as clay, vermiculite, peat and charcoal [15]. Care should be taken, when selecting microbial carriers, to ensure they have no negative impact on the environment or the microbe itself $[15,38]$. Although they are easy to handle and work with, liquid carriers may require specialised storage conditions (cool conditions that necessitate a cooling mechanism) for a long shelf life [23], which makes their marketing and use in developing countries difficult, due to limited and unstable power supply on most farms. Solid formulations, on the other hand, are bulky and may require larger storage facilities, when compared to liquids. However, materials such as peat have an outstanding reputation as inoculant carriers, and are successfully used in both North and South America [23]. The formulation method opted for should ensure the affordability of the final product by the target market, since a very expensive product is likely to meaningfully increase production costs, which is undesirable. For instance, sterile carriers are preferred over nonsterile carriers [23], however the former are costlier than the latter, which may make them unaffordable to many farmers across the globe. The formulation method should also ensure the compatibility of the inoculant with agronomic practices, such as weed control methods, irrigation, etc.

Once a formulated product exhibits positive responses, in field and greenhouse trials, it is put on the market for accessibility by farmers. While the isolation and characterisation of microbial strains from their natural habitats is largely done by academic research institutions, the production of microbial inoculants for commercial purposes is dominated by registered companies, which obtain patents and rights over specific inoculants. Table 3 below shows such microbial based products on the market as plant growth stimulants. 
Table 3. Examples of microbial inoculants currently available on the market, and their producing companies.

\begin{tabular}{|c|c|c|c|c|}
\hline Inoculant & Country & Producer & Use & Reference \\
\hline Bacillus megaterium & Sri Lanka & BioPowerLanka & $\begin{array}{l}\text { Phosphorus } \\
\text { solubilisation }\end{array}$ & [135] \\
\hline $\begin{array}{c}\text { Pseudomonas striata, B. Polymyxa and } \\
\text { B.megaterium consortium }\end{array}$ & India & AgriLife & $\begin{array}{l}\text { Phosphorus } \\
\text { solubilisation }\end{array}$ & [135] \\
\hline Acidithiobacillus ferrooxidans & India & AgriLife & Iron mobilization & [135] \\
\hline $\begin{array}{l}\text { Trichoderma and Bradyrhizobium spp. } \\
\text { (Excalibre-SA) consortium }\end{array}$ & USA & $A B M^{\circledR}$ & $\begin{array}{c}\text { N fixation } \\
\text { Growth stimulation }\end{array}$ & [18] \\
\hline $\begin{array}{c}\text { BIODOZ }^{\circledR} \\
\text { (B. japonicum) }\end{array}$ & Denmark & Novozymes & Nitrogen fixation & [134] \\
\hline $\begin{array}{l}\text { Cell-Tech }^{\circledR} \\
\text { (B.japonicum) }\end{array}$ & Belgium & Monsanto (Bayer) & Nitrogen fixation & [134] \\
\hline $\begin{array}{l}\text { Nitragin }^{\circledR} \\
\text { S. meliloti }\end{array}$ & Belgium & $\begin{array}{c}\text { Monsanto BioAg }{ }^{T M} \\
\text { (Bayer) }\end{array}$ & Nitrogen fixation & [134] \\
\hline $\begin{array}{c}\text { Cedomon }^{\circledR} \\
\text { Pseudomonas chlororaphis }\end{array}$ & Sweden & BioAgriAB & Biopesticide & [134] \\
\hline $\begin{array}{c}\text { Sheathguard }{ }^{T M} \\
\text { Pseudomonas fluorescens }\end{array}$ & India & AgriLife & Biopesticide & [134] \\
\hline $\begin{array}{c}\text { Galltrol }^{\circledR}-A \\
\text { Agrobacterium radiobacter }\end{array}$ & USA & AgBioChem & Biopesticide & [134] \\
\hline $\begin{array}{c}\text { HISTICK }^{\circledR} \\
\text { Bradyrhizobium japonicum }\end{array}$ & Germany & $B A S F S E$ & Nitrogen fixation & [135] \\
\hline $\begin{array}{c}\text { Bacillus }+ \text { Pseudomonas }+ \text { Lactobacillus }+ \\
\text { Saccharomyces spp. }\end{array}$ & Canada & EVL Inc & Biostimulant & \\
\hline $\begin{array}{c}\text { Xen Tari } \\
\text { (Bacillus thuringiensis) }\end{array}$ & USA & Valent USA & Biopesticide & [136] \\
\hline VOTIVO FS seed treatment (Bacillus firmus) & USA & Bayer & Biopesticide & [136] \\
\hline VectoLex FG (Bacillus sphaericus) & USA & Valent Biosciences & Biopesticide & [136] \\
\hline Venerate XC (Burkholderia rinojensis) & USA & $\begin{array}{l}\text { Marrone Bio } \\
\text { Innovations }\end{array}$ & Biopesticide & [136] \\
\hline Zequanox (Pseudomonas fluorescens) & USA & $\begin{array}{l}\text { Marrone Bio } \\
\text { Innovations }\end{array}$ & Biopesticide & [136] \\
\hline $\begin{array}{c}\text { BotaniGard ES/WP, Mycotrol (Beauveria } \\
\text { bassiana) }\end{array}$ & USA & Lam International & Biopesticide & [136] \\
\hline Naturalis L (Beauveria bassiana) & USA & Troy BioSciences & Biopesticide & [136] \\
\hline BioCeres WP (Beauveria bassiana) & USA & BioSafe & Biopesticide & [136] \\
\hline $\begin{array}{c}\text { Met-52 EC and Met-52 G (Metarhizium } \\
\text { brunneum (anisopliae s.L.) }\end{array}$ & USA & Novozymes & Biopesticide & [136] \\
\hline MeloCon WG (Purpureocillium lilacinum) & USA & Bayer & Biopesticide & [136] \\
\hline Cyd-X, Cyd-X HP (Cydia pomonella (CpGV) & USA & Certis USA & Biopesticide & [136] \\
\hline FruitGuard (Plodia interpunctella GV & USA & Agrivir & Biopesticide & [136] \\
\hline Serenade (Bacillus subtilis QST 713) & & Agraquest & Biocontrol & [79] \\
\hline $\begin{array}{c}\text { Bacillus firmus I-1582 WP5 (B. firmus } \\
\text { I-1582) }\end{array}$ & & Bayer Crop Science & Biocontrol & [79] \\
\hline $\begin{array}{c}\text { Cedomon (Pseudomonas chlororaphis } \\
\text { MA342) }\end{array}$ & & Bioagri & & [79] \\
\hline Proradix (Pseudomonas sp. DSMZ 13134) & & $\begin{array}{l}\text { Sourcon-Padena } \\
\text { Germany, Itary }\end{array}$ & Biocontrol & [79] \\
\hline $\begin{array}{l}\text { Novodor (B. thuringiensis ssp. tenebrionis } \\
\text { NB 176) }\end{array}$ & USA & Valent Bioscience & Biocontrol & [79] \\
\hline
\end{tabular}




\section{Limitations to Global Use of Microbial Inoculants}

Although microbial inoculants are viewed as the most viable hope, with regard to sustainable agriculture in the face of climate change, their use and adoption globally are still wanting, due to a range of reasons, that vary between developed and developing countries. Adaptation to use of microbial inoculants is developing at a relatively faster pace [24] in the developed world than in developing areas, such as Africa, where their use is restricted by limited availability of resources and knowledge, among other factors. In the developed world, microbial use is slowed largely by inconsistencies in enhancing plant growth, in which case crop producers opt for chemicals, which generally provide stable results. There are many cases where the excellent performance of an inoculant observed during pre-commercialisation trials does not translate to efficiency on farmers' fields. Even when it does, sometimes the results are not consistent, which frustrates the farmers. Some of these inconsistences may be attributed to biotic and abiotic soil factors and plant factors which directly or indirectly affect the introduced microorganism(s) [23]. For instance, some inoculants are cultivar and species specific, in that applying them outside the target species will yield no results. Soil factors such as salinity and temperature are dynamic and affect the survival and effectiveness of the applied microbial strains. This implies that soil conditions should always be favorable for the introduced microbe, otherwise inconsistencies are bound to prevail. Therefore, there is a need to sensitise farmers regarding the proper use of microbial products to minimise such inconsistencies. Unless sensitisation is properly conducted, we cannot rule out inappropriate practices such as farmers applying rhizobial inoculants together with high doses of nitrogen fertilizer, expecting better results than the inoculant or fertilizer used alone. In fact, nitrogen fertilizer will inhibit biological nitrogen fixation. Similarly, applying a biocontrol to a soil or plant that lacks the pathogen it can antagonise/suppress may not yield results. It is also important to understand the status of the soil/plant as the application of microbial inoculants may inhibit plant growth where the soil/plant already contains optimal concentrations of the compound that the microbe produces to enhance plant growth. For instance, application of IAA producing PGPM on plants with an already optimal concentration of IAA may yield negative effects on the plant, due to excess IAA [43]. Understanding soil conditions will also guide the farmer regarding how often to apply the inoculant. Some require seasonal, annual or even twice in a season application, while after some time, application may not be necessary, especially where the microbe establishes reasonable populations in the soil. Successful microbial inoculants employ mechanisms that give them a competitive advantage over the native strains. For instance, rhizobia and mycorrhizal fungi have a signaling system with their host plants, which gives them an advantage over their competitors. Introduced microbes may also outcompete native microbes through the production of antimicrobials, which may kill or deter other microbes, as well as the production of siderophores that give them a competitive advantage over other microbes for iron resources in the soil, hence proliferating better, especially in iron limited soils [14]. Nevertheless, it is important to increase the competitive advantage of introduced microbes, by ensuring high microbial concentrations in the inoculant and use of adequate formulations [18]. With approaches such as metagenomics, the microbial population of the target environment can be studied, and potential PGPM studied for their ability to out compete the latter in field, greenhouse and laboratory conditions. However, this may not be an easy task, given that microbial populations in crop production fields may differ meaningfully due to a wide range of factors. Location and plant specific nature of some phytomicrobiome elements for inoculant production should also be prioritised, since such microbes, to a great extent, are more adapted to the environment and/or plant conditions, which may increase their chances of survival and persistence in the soil. The idea of using microbial consortia may also work to our benefit, as will be discussed below. This does not, however, disqualify single strain inoculants; their advantages are also discussed below.

In less developed countries, especially in sub-Saharan Africa, reasons for low adoption also vary between large- and small-scale farmers. For large-scale farmers, such as those in Zimbabwe, South Africa and Kenya, the ineffectiveness of many microbe-based products in the field contributes meaningfully to the low adoption of microbial inoculants $[137,138]$. For small scale farmers, costs and 
inadequate knowledge of such products are the major drivers. These two factors, especially costs, also limit the use of other agricultural inputs, such as high-quality seed. Exceptions can be made for a smaller group of small scale farmers, whose farms' researchers run experiments/field trials, because then, they can obtain access to the inputs from researchers largely free of charge, otherwise, they mostly depend on crop rotations (which are sometimes not properly done) and animal manures, while others just grow their preferred crops year in year out. The lack of knowledge can be attributed to the large gap between research and extension. Researchers achieve good findings, but due to poor funding and poor dissemination techniques, this knowledge never reaches the farmer [138]. Publications do not help much, because many small-scale farmers are illiterate, and even those who can read have limited access to technologies such as smart phones, computers and the internet. It should be noted that many small-scale farmers are also low-income earners, who struggle to meet their basic needs. In countries where governments are not directly involved in the distribution of agricultural inputs, dealers may not be willing to extend products to people who they well know cannot afford them, which leads to unavailability of and/or inaccessibility of the products by the farmers. In such cases, intervention strategies should definitely be at least a bit different and more vigorous. First and foremost, the knowledge of existence of PGPM technology needs to be spread to these largely small scale farmers. Projects like N2 Africa have done a good job in trying to spread the BNF technology, although more effort is still needed. Extension officers should be updated on new findings and products, and be properly facilitated to extend this knowledge to the farmers. Governments may consider subsidizing products and getting directly involved in their distribution to the farmers. Promiscuous soybean varieties are already a good strategy of eliminating the need for inoculation. It would be better to develop strategies that enable the use of farm-based PGPM inoculants, as many farmers have limited access to agro-input markets, in part due to poor transport networks. Locally made cooling facilities such as charcoal based refrigerators and unglazed clay pots may also be helpful. However, the former would be a contradictory measure, given that it would encourage deforestation. The whole sensitisation process should involve all stakeholders, such as governments, extension officers, agricultural schools, and private companies that contract small scale farmers to grow crops for them for use as raw materials. The latter, especially, provide the farmer with chemicals such as pesticides and fertilizers; therefore, their involvement cannot be ignored.

\section{Microbial Consortia}

In order to address issues associated with the use of single strains as inoculants, microbial consortia have gained popularity. This may be relevant, especially now that the prevalence of both biotic and abiotic stresses due to climate change are likely to increase. Microbial consortia technology involves the use of more than one microbial species in a single inoculant product. The microbes may have the same or different modes of action $[18,70,89]$, and may be from different phyla, genera or even other groupings, for example, a combination of bacterial and fungal strains. Microbial consortia may have an advantage over single strains when the species synergistically interact and confer benefits to each other $[70,71,89,117]$. For instance, one strain may breakdown a substrate, unavailable to other species, converting it into forms that the other members of the consortium can utilise as a source of nutrients [14], or produce exopolysaccharides which offer protection against stress to all members of the consortium [134], produce compounds which are signals that activate plant growth promotion capability of other members of the consortium, through the production of plant growth stimulating compounds, that they would otherwise not produce, for instance, in pure culture. In cases where microbes with the same mode of action are used, members may have varying tolerance to different biotic and abiotic stresses, which enhances survival of at least a member that will confer intended benefits to the plant. In the case of different modes of action, these complement each other and confer a more effective benefit to the plant. It could also be that some members of the consortium are simply helpers of the strains meant to benefit the plant. Such helper strains, for instance mycorrhiza helper bacteria, should facilitate the target strain in plant colonisation, conferring benefits to the plant. 
Researchers have reported inefficient strains that became efficient in a consortium. For example, Santhanam et al. [89] observed that the inclusion of two bacterial strains with insignificant effects on mortality of sudden wilt pathogens in tobacco, in a consortium with three other bacteria improved resistance of plants to the same pathogen, in comparison to the consortium of 3 used alone. Mycorrhizal fungi, in association with a helper bacterium, may have better established mycelia and plant root colonisation, if the bacterium produces substances that directly enhance the germination of fungal spores, or indirectly enhance the establishment of mycorrhiza through the production of antimicrobials that reduce competition from other microbes or minor pathogens [14].

Because of the interaction advantage, some microbes perform better in microbial consortia than when applied individually [70,89]. However, the reverse is true for some PGPM species, as reported by other researchers $[70,92,100]$. Therefore, the role that single strain inoculants play cannot be written off easily, especially because microbial consortia also have their shortcomings. Coming up with effective compatible combinations in which all members actively benefit the plant can be challenging, practically given that some members of the consortium may produce compounds lethal to other members [133]. Even if the produced compounds do not go to the extreme of killing other members, they may cause a shutdown of their plant growth promoting system, or interfere with their growth, as de Vrieze et al. [70] observed in a consortium of five Pseudomonas strains. In such cases, it is probable that only a subset of the consortium members will actively benefit the plant, the rest being "dormant" or dead. Difficulties concerning the formulation of microbial consortia may also be associated with the variations in optimal growth conditions. For more than one species, or even genus, creating conditions that will favour all members while retaining their ability to promote plant growth may not be easy. Finally, manufacturing consortia can be challenging, as very small changes at the outset can result in very different levels of consortium members in the final product, resulting in product inconsistencies.

\section{Microbial Compounds as "Inoculants"}

The use of microbial compounds as "inoculants" is slowly gaining popularity after successful trials [139-145]. To be a true inoculant, the material must contain living cells that colonize the plant. In this case, the technology may be the product of microbial growth and may be more valuable as a result of climate change were biotic and abiotic factors may lower or completely halt the effectiveness of microbial cell based inoculants. This practice involves the separation of cell free supernatant from microbial cells, and the subsequent separation and purification of the compound from the cell-free supernatant, mainly through high pressure liquid chromatography (HPLC). The pure compound is then tested for its ability to promote plant growth under greenhouse and field conditions, prior to commercialisation. Before commercialisation, other tests, such as the effect of the compound on non-target organisms and humans, as well as checks regarding legal regulations, are usually carried out. The effect of the compound on non-target organisms such as plants, humans and animals ought to be substantially understood too, as with studying the residual effects of the compound (how much of it remains in the edible parts of the plant, and in the soil, following application). Therefore, before any compound can be commercialised, its ability to be purified, and produced on a large scale, should be verified [143]. The compound should be identified and characterised based on its physiological and biological properties.

The efficacy and type of microbial bioactive compounds produced are influenced by microbial species and conditions to which the PGPM is exposed. Slight alterations in growth conditions may result in different compounds, produced at different levels, and with varying degrees of efficacy. For instance, varying the $\mathrm{pH}$, a Pseudomonas species culture caused it to produce different phenazine compounds with varying efficacy against Fusarium oxysporum f. sp. radicis-lycopersici [143]. Sometimes, the PGPM has to be exposed to stressful conditions before it will produce bioactive compounds, as such compounds may only be produced to enhance the survival of the microorganism under stressful conditions. Therefore, it is important to have an adequate understanding of the conditions under which a certain PGPM will produce plant growth stimulating compounds. 
So far, not many (compared to microbial strains) bioactive compounds have been identified for use in crop production. The Smith laboratory at McGill University has thuricin17 and lipochitooligosaccharide (LCO). Thuricin 17 is a bacteriocin secreted by Bacillus thuringiensis, a non-symbiotic endophytic bacterium. The compound is known to have anti-microbial properties, which gives Bacillus thuringiensis a competitive advantage over other bacteria of the same grouping [140]. After a series of experiments, thuricin 17 was discovered to have growth promoting properties for tomato, soybean, canola, arabidopsis, and rapeseed and switch grass [117,140-142,144,145]. More trials are on-going, and the technology has yet to be commercialised. Lipo-chitooligosaccharide, on the other hand, is produced by rhizobia, as a signal to its host plants [139]. Formerly extensively studied for its role in the nodulation process, the compound is currently patented and being marketed by Novozymes as a plant growth stimulant, where its effects are greatest under abiotic stress conditions. Other compounds such as phenazine-1-carboxylic acid (PCA) have also been commercialised [143,146-153]. Table 4 shows the various compounds with potential use as agro-inputs. Some of them are already commercialised.

Table 4. Microbial compounds of agricultural importance.

\begin{tabular}{|c|c|c|c|c|}
\hline Compound & $\begin{array}{l}\text { Producing } \\
\text { Microbe }\end{array}$ & Function & Comment & Reference \\
\hline$L C O$ & $\begin{array}{l}\text { Bradyrhizobium } \\
\text { japonicum }\end{array}$ & Biostimulant & $\begin{array}{l}\text { Stimulates plant growth under } \\
\text { stressed and non stressed conditions. }\end{array}$ & {$[117,146]$} \\
\hline Thuricin17 & $\begin{array}{l}\text { Bacillus } \\
\text { thuringiensis }\end{array}$ & Biostimulant & $\begin{array}{c}\text { Enhances growth of different crops eg } \\
\text { Soybean in stressed and non stressed } \\
\text { conditions }\end{array}$ & {$[141,142]$} \\
\hline Anisomycin & Streptomyces sp. & herbicide & Effective against Digitaria spp. & [149] \\
\hline $\begin{array}{l}\text { Phenazine-1-carboxyamide } \\
\text { (PCN) }\end{array}$ & Pseudomonas spp. & biocontrol & $\begin{array}{l}\text { It is effective against; Fusarium } \\
\text { oxysporum } f . \text { sp. Radicis-lycopersici, } \\
\text { Xanthomonas oryzae pv. Oryzae, } \\
\text { Rhizoctonia solani, Botrytis cinerea }\end{array}$ & {$[143,148,149,151]$} \\
\hline $\begin{array}{l}\text { Phenazine-1-carboxylic } \\
\text { acid }(P C A)\end{array}$ & Pseudomonas spp. & biocontrol & $\begin{array}{c}\text { It is effective against Fusarium } \\
\text { oxysp.orum } f . \text { sp.Radicis-lycopersici, } \\
\text { Colletotrichum orbiculare, } \\
\text { Gaeumannomyces graminis var. } \\
\text { tritici, Phytophthora } \\
\text { capsici }\end{array}$ & $\begin{array}{c}{[143,146,149,152,} \\
153]\end{array}$ \\
\hline Pyocyanin (PYO) & Pseudomonas spp. & biocontrol & $\begin{array}{l}\text { Effective against: Sclerotium rolfsii, } \\
\text { Macrophomina phaseolina }\end{array}$ & [154-156] \\
\hline Pyrrolnitrin & $\begin{array}{c}\text { Burkholderia } \\
\text { pyrrocinia } 2327\end{array}$ & biocontrol & $\begin{array}{l}\text { It has antifungal properties against; } \\
\text { Ralstonia solani, Phytophthora } \\
\text { capsici, and Fusarium oxysporum }\end{array}$ & {$[157,158]$} \\
\hline Phencomycin & $\begin{array}{l}\text { Burkholderia glumae } \\
\text { 411gr-6 }\end{array}$ & biocontrol & $\begin{array}{l}\text { Effective against; Alternaria } \\
\text { brassicicola, Aspergillus oryzae, } \\
\text { Cladosporium cucumerinum, } \\
\text { Colletotrichum gloeosporioides }\end{array}$ & [159] \\
\hline Ornibactin & $\begin{array}{c}\text { Burkholderia } \\
\text { contaminans MS14 }\end{array}$ & biocontrol & $\begin{array}{l}\text { Siderophore with biocontrol activity } \\
\text { against Erwinia amylovora, Ralstonia } \\
\text { solanacearum, Pseudomonas syringae } \\
\text { B301, Clavibacter michiganensis } \\
\text { subsp. michiganensis }\end{array}$ & {$[160]$} \\
\hline Iturin A2 & Bacillus subtilis B47 & biocontrol & $\begin{array}{c}\text { Effective against fungi; Bipolaris } \\
\text { maydis }\end{array}$ & [161] \\
\hline Mycosubtilin & Bacillus subtilis & biocontrol & $\begin{array}{c}\text { Has anti fungal properties, effective } \\
\text { against; Bremia lactucae }\end{array}$ & [162] \\
\hline Herboxidiene & $\begin{array}{l}\text { Streptomyces sp. } \\
\text { A7847 }\end{array}$ & herbecide & Effective on a number of weed sp. & [163] \\
\hline Phosphinothricin & $\begin{array}{l}\text { Streptomyces } \\
\text { hygroscopicus }\end{array}$ & herbecide & & \\
\hline
\end{tabular}


Table 4. Cont.

\begin{tabular}{ccccc}
\hline Compound & $\begin{array}{c}\text { Producing } \\
\text { Microbe }\end{array}$ & Function & Comment & Reference \\
\hline Cyanobacterin & Scytonema hofmanni & herbecide & $\begin{array}{c}\text { Effective on cynobacteria, algae and } \\
\text { higher plants }\end{array}$ & {$[164]$} \\
\hline Avermectin & $\begin{array}{c}\text { Streptomyces } \\
\text { avermitilis }\end{array}$ & $\begin{array}{c}\text { Insectide } \\
\text { nematocide }\end{array}$ & $\begin{array}{c}\text { Effective against Spider mites, Citrus } \\
\text { red mite, horn worms, army worms, } \\
\text { etc. }\end{array}$ & {$[165]$} \\
\hline
\end{tabular}

\section{Microbial Cells or Microbial Compounds?}

Given the current understanding, a question would be, what should a crop producer adopt, given a choice between the microbial cells and microbial compound based products. The answer to such a question cannot be as definite as that specific factors may call for either of the two, or even the use of both simultaneously. Before one reaches the level of farmer preferences, soil and environmental factors as well as economic implications, intended use and handling may be major considerations. For instance, in the reclamation of areas heavily affected by abiotic stress, use of microbial cells may not be a good idea, if they are not able to survive some harsh conditions. Even if they did, the efficacy of their plant growth promotion capacity may be greatly affected. Compounds, on the other hand, are less affected by such abiotic stresses, and hence have a greater chance of being successful under such conditions. The use of compounds or both compound(s) and microbial cells may be desirable, especially when an abiotic stress such as drought interrupts signaling between plant and PGPM. In such a case, external application of the signal may rectify the disruption. Prudent et al. [142] observed a 17\% increase in soybean biomass under drought conditions following co-inoculation with Bradyrhizobium japonicum and thuricin17, compared to inoculation with the rhizobial cells alone. The use of microbial compounds may also be a better choice in cases where the microbe is a facultative pathogen, such as Agrobacterium spp. [92]. In such cases, the pathogen effect of the microbe on plants is minimised. Application of microbial compounds may also benefit a wider range of crop species compared to microbial cells, given that many microbes can be at least somewhat species specific. A case would be that of lipochitooligosaccharides (LCOs), which can be utilised to enhance growth of legumes and non-leguminous crops [148], under stressed and non-stressed conditions [115,137], but to a greater extent, under stress conditions. For instance, LCOs enhanced fruit and flower production in tomato (Lycopersicon esculentum) plants [148], and stimulated the growth of soybean and corn plants [139]. The compound was also reported to enhance the germination of soybean seeds subjected to high $\mathrm{NaCl}$ concentrations [117] and canola [145]. Such benefits from LCO would not be provided to these crops had Bradyrhizobium japonicum been applied. Compounds are also less bulky and less costly, in most cases requiring small doses to be efficient. This relieves crop producers of storage and transportation concerns.

However, there are scenarios where the use of microbial cells is inevitable. For instance, the role that rhizobia play in nitrogen fixation, or mycorrhizae in P mobilisation and acquisition by plant roots could not be fulfilled by microbial compounds. Nitrogen fixing bacteria cannot be substituted by compounds in areas were $\mathrm{N}$ is limiting. Microbial cells have the potential to establish microbial populations in the rhizosphere, which may eliminate the need for further inoculation, a characteristic most farmers would desire, since it not only has positive financial implications, but also saves labour. Based on this, it is safe to assume that marketing companies would opt for compounds, since they guarantee continuous sales. However, the long and laborious process of isolating and purifying microbial compounds may also contribute to their scarcity and willingness of some researchers and companies to take that route.

\section{Way Forward and Recommendations}

With climate change conditions increasing, and the desperate need to come up with sustainable approaches of enhancing crop productivity to meet the food demand of the growing population, 
microbes are a prominent source of hope. However, a great deal still needs to be done to bridge the gap between their use in developed and developing countries. More research should be done to address issues of inconsistencies observed on crop producers' fields, following the use of microbial inoculants. It is obvious that single strains and consortia, or microbial cells and microbial compounds are issues that need to be evaluated on a case-by-case basis. Therefore, a better suggestion would be that more research be done to provide consumers with options that can address their unique needs, while being economically viable.

\section{Conclusions}

Lowering the effects of climate change on crop production, through reducing greenhouse gas emissions, is one of the major focuses of researchers in recent times. With proper manipulation, plant growth promoting microorganisms and compounds, they produce have potential to enhance growth and yield of plants exposed to biotic and biotic stress(es). This can complement other strategies, such as conservation farming and breeding for stress tolerant crop cultivars, to create an integrated approach of enhancing crop production in the face of climate change. Given that the prevalence of stress is predicted to increase with climate change, more research is needed to come up with better and more effective alternatives of utilising PGPM technology; not only to enhance plant growth, but also to reduce greenhouse gas emissions from the agricultural sector, which is a meaningful contributor.

Author Contributions: J.N. gathered all reading material and wrote the review; D.L.S. did all the editing and guidance on scientific knowledge. All authors have read and agreed to the published version of the manuscript.

Funding: This research was funded by the Natural Science and Engineering Research Council of Canada grant number RGPIN 2020-07047.

Conflicts of Interest: There is no conflict of interest.

\section{References}

1. Lott, F.C.; Christidis, N.; Stott, P.A. Can the 2011 East African drought be attributed to human-induced climate change? Geophys. Res. Lett. 2013, 40, 1177-1181. [CrossRef]

2. Rossi, F.; Olguin, E.J.; Diels, L.; de Philippis, R. Microbial fixation of $\mathrm{CO}_{2}$ in waterbodies and in drylands to combat climate change, soil loss and desertification. New Biotechnol. 2015, 32, 109-120. [CrossRef]

3. Bradley, B.A.; Curtis, C.A.; Chambers, J.C. Bromus Response to Climate and Projected Changes with Climate Change. In Exotic Brome-Grasses in Arid and Semiarid Ecosystems of the Western US; Germino, M., Chambers, J., Brown, C., Eds.; Springer Series on Environmental Management; Springer: Cham, Switzerland, 2016; pp. 257-274. [CrossRef]

4. Richards, M.B.; Wollenberg, E.; van Vuuren, D. National contributions to climate change mitigation from agriculture: Allocating a global target. Clim. Policy 2018, 18, 1271-1285. [CrossRef]

5. Loboguerrero, A.M.; Campbell, B.M.; Cooper, P.J.M.; Hansen, J.W.; Rosenstock, T.; Wollenberg, E. Food and Earth Systems: Priorities for Climate Change Adaptation and Mitigation for Agriculture and Food Systems. Sustainability 2019, 11, 1372. [CrossRef]

6. IPCC. 2014: Climate Change 2014: Synthesis Report. Contribution of Working Groups I, II and III to the Fifth Assessment Report of the Intergovernmental Panel on Climate Change; Pachauri, R.K., Meyer, L.A., Eds.; IPCC: Geneva, Switzerland, 2014; p. 151.

7. Porter, J.R.; Xie, L.; Challinor, A.J.; Cochrane, K.; Howden, S.M.; Iqbal, M.M.; Lobell, D.B.; Travasso, M.I. Food security and food production systems. In Climate Change 2014: Impacts, Adaptation, and Vulnerability Part A: Global and Sectoral Aspects. Contribution of Working GroupII to the Fifth Assessment Report of the Intergovernmental Panel on Climate Change; Field, C.B., Barros, V.R., Dokken, D.J., Mach, K.J., Mastrandrea, M.D., Bilir, T.E., Chatterjee, M., Ebi, K.L., Estrada, Y.O., Genova, R.C., et al., Eds.; Cambridge University Press: Cambridge, UK; New York, NY, USA, 2014; pp. 485-533.

8. Dawson, T.P.; Perryman, A.H.; Osborne, T.M. Modelling impacts of climate change on global food security. Clim. Chang. 2016, 134, 429-440. [CrossRef] 
9. Bouwer, L.M.; Bubeck, P.; Aerts, J.C. Changes in future flood risk due to climate and development in a Dutch polder area. Glob. Environ. Chang. 2010, 20,463-471. [CrossRef]

10. Mirza, M.M.Q. Climate change, flooding in South Asia and implications. Reg. Environ. Chang. 2011, 11, 95-107. [CrossRef]

11. Nam, W.; Hayes, M.J.; Svoboda, M.D.; Tadesse, T.; Wilhite, D.A. Drought hazard assessment in the context of climate change for South Korea. Agric. Water Manag. 2015, 160, 106-117. [CrossRef]

12. Barea, J.M. Future challenges and perspectives for applying microbial biotechnology in sustainable agriculture based on a better understanding of plant-microbiome interactions. J. Soil Sci. Plant Nutr. 2015, 15, 261-282. [CrossRef]

13. Gupta, G.; Parihar, S.S.; Ahirwar, N.K.; Snehi, S.K.; Singh, V. Plant Growth Promoting Rhizobacteria (PGPR): Current and Future Prospects for Development of Sustainable Agriculture. Microb. Biochem. Technol. 2015, 7, 96-102. [CrossRef]

14. Bender, S.F.; Wagg, C.; van der Heijden, M.G.A. An Underground Revolution: Biodiversity and Soil Ecological Engineering for Agricultural Sustainability. Trends Ecol. Evol. 2016, 31, 440-452. [CrossRef] [PubMed]

15. Babalola, O.O.; Glick, B.R. The use of microbial inoculants in African agriculture: Current practice and future prospects. J. Food Agric. Environ. 2012, 10, 540-549.

16. Smith, D.L.; Subramanian, S.; Lamont, J.R.; Bywater-Ekegärd, M. Signaling in the phytomicrobiome: Breadth and potential. Front. Plant Sci. 2015, 6, 709. [CrossRef] [PubMed]

17. Smith, D.L.; Gravel, V.; Yergeau, E. Signaling in the Phytomicrobiome. Front. Plant Sci. 2017, 8, 611. [CrossRef] [PubMed]

18. Backer, R.; Rokem, J.S.; Ilangumaran, G.; Lamont, J.; Praslickova, D.; Ricci, E.; Subramanian, S.; Smith, D.L. Plant Growth-Promoting Rhizobacteria: Context, Mechanisms of Action, and Roadmap to Commercialization of Bio stimulants for Sustainable Agriculture. Front. Plant Sci. 2018, 9, 1473. [CrossRef]

19. Hartmann, A.; Rothballer, M.; Hense, B.A.; Schröder, P. Bacterial quorum sensing compounds are important modulators of microbe-plant interactions. Front. Plant Sci. 2014, 5, 131. [CrossRef]

20. Sánchez-Cañizares, C.; Jorrín, B.; Poole, P.S.; Tkacz, A. Understanding the holobiont: The interdependence of plants and their microbiome. Curr. Opin. Microbiol. 2017, 38, 188-196. [CrossRef]

21. Compant, S.; Samad, A.; Faist, H.; Sessitsch, A. A review on the plant microbiome: Ecology, functions and emerging trends in microbial applications. J. Adv. Res. 2019, 19, 29-37. [CrossRef]

22. Berg, M.; Koskella, B. Nutrient and dose dependent protection against a plant pathogen. Curr. Biol. 2018, 28, 2487-2492. [CrossRef]

23. Bashan, Y.; de-Bashan, L.E.; Prabhu, S.R.; Hernandez, J. Advances in plant growth-promoting bacterial inoculant technology: Formulations and practical perspectives (1998-2013). Plant Soil 2014, 378, 1-33. [CrossRef]

24. Alori, E.T.; Dare, M.O.; Babalola, O.O. Microbial Inoculants for Soil Quality and Plant Health. In Sustainable Agriculture Reviews; Lichtfouse, E., Ed.; Springer: Cham, Switzerland, 2017; Volume 22, pp. 281-307. [CrossRef]

25. Malusa, E.; Sas-Paszt, L.; Ciesielska, J. Technologies for Beneficial Microorganisms Inocula Used as Biofertilizers. Sci. World J. 2012, 2012, 491206. [CrossRef]

26. Silva, E.C.; Nogueira, R.J.M.C.; Silva, M.A.; Albuquerque, M.B. Drought Stress and Plant Nutrition. Plant Stress 2011, 5, 32-41.

27. DaMatta, F.; Loos, R.A.; Silva, E.A.; Loureiro, M.E.; Ducatti, C. Effects of soil water déficit and nitrogen nutrition on water relations and photosynthesis of pot-grown Coffea canephora Pierra. Trees 2002, 16, 555-558. [CrossRef]

28. Tietema, A.; De Boer, W.; Riemer, L.; Verstraten, J.M. Nitrate production in nitrogen saturated acid forest soils: Vertical distributions and characteristics. Soil Biol. Biochem. 1992, 24, 235-240. [CrossRef]

29. Tripathi, D.K.; Singh, S.; Gaur, S.; Singh, S.; Yadav, V.; Liu, S.; Singh, V.P.; Sharma, S.; Srivastava, P.; Prasad, S.M.; et al. Acquisition and Homeostasis of Iron in Higher Plants and Their Probable Role in Abiotic Stress Tolerance. Front. Environ. Sci. 2018, 5, 86. [CrossRef]

30. Wang, W.; Zheng, Q.; Shen, Q.; Guo, S. The Critical Role of Potassium in Plant Stress Response. Int. J. Mol. Sci. 2013, 14, 7370-7390. [CrossRef]

31. Waraich, E.A.; Ahmad, R.; Halim, A.; Aziz, T. Alleviation of temperature stress by nutrient management in crop plants: A review. J. Soil Sci. Plant Nutr. 2012, 12, 221-244. [CrossRef] 
32. Waraich, E.A.; Ahmad, R.; Ashraf, M.Y.; Saifullah; Ahmad, M. Improving agricultural water use efficiency by nutrient management in crop plants. Acta Agriculturae Scandinavica. Sect. B Plant Soil Sci. 2011, 61, 291-304. [CrossRef]

33. Karmakar, R.; Das, I.; Dutta, D.; Rakshit, A. Potential Effects of Climate Change on Soil Properties: A Review. Sci. Int. 2016, 4, 51-73. [CrossRef]

34. Wu, F.U.; Bao, W.; Li, F.L.; Wu, N. Effects of water stress and nitrogen supply on leaf gas exchange and fluorescence parameters of Sophora davidii seedlings. Photosynthetica 2008, 46, 40-48. [CrossRef]

35. Faye, I.; Diouf, O.; Guisse', A.; Se'ne, M.; Diallo, N. Characterizing Root Responses to Low Phosphorus in Pearl Millet [Pennisetum glaucum (L.) R. Br.]. Agron. J. 2006, 98, 1187-1194. [CrossRef]

36. Alori, E.T.; Fawole, O.B. Impact of chemical inputs on arbuscular mycorrhiza spores in soil: Response of AM Spores to fertilizer and herbicides. Alban J. Agric. Sci. 2017, 16, 10-13.

37. Lal, R. Restoring Soil Quality to Mitigate Soil Degradation. Sustainability 2015, 7, 5875-5895. [CrossRef]

38. Alori, E.T.; Babalola, O.O. Microbial Inoculants for Improving Crop Quality and Human Health in Africa. Front. Microbiol. 2018, 9, 2213. [CrossRef] [PubMed]

39. Naamala, J.; Jaiswal, S.K.; Dakora, F.D. Microsymbiont diversity and phylogeny of native Bradyrhizobia associated with soybean (Glycine max L. Merr.) nodulation in South African soils. Syst. Appl. Microbiol. 2016, 39, 336-344. [CrossRef]

40. Graham, J.H.; Leonard, R.T.; Menge, J.A. Membrane-Mediated Decrease in Root Exudation Responsible for Phorphorus Inhibition of Vesicular-Arbuscular Mycorrhiza Formation. Plant. Physiol. 1981, 68, 548-552. [CrossRef]

41. Sprent, J.I.; Stephens, J.H.; Rupela, O.P. Environmental effects on nitrogen fixation. In World Crops: Cool Season Food Legumes; Summerfield, R.J., Ed.; Current Plant Science and Biotechnology in Agriculture; Springer: Dordrech, The Netherlands, 1988; Volume 5, pp. 801-810. [CrossRef]

42. Marschner, H.; Dell, B. Nutrient uptake in mycorrhizal symbiosis. Plant Soil 1994, 159, 89-102. [CrossRef]

43. Glick, B.R. Plant growth promoting bacteria: Mechanisms and applications. Scientifica 2012, 2012, 1-15. [CrossRef]

44. Goldstein, A.H.; Krishnaraj, P.U. Phosphate solubilizing microorganisms vs. phosphate mobilizing microorganisms: What separates a phenotype from a trait? In First International Meeting on Microbial Phosphate Solubilization. Developments in Plant and Soil Sciences; Velázquez, E., Rodríguez-Barrueco, C., Eds.; Springer: Dordrecht, The Netherlands, 2007; Volume 102, pp. 203-213. [CrossRef]

45. Meding, S.M.; Zasoski, R.J. Hyphal-mediated transfer of nitrate, arsenic, cesium, rubidium, and strontium between arbuscular mycorrhizal forbs and grasses from a California oak woodland. Soil Biol. Biochem. 2008, 40, 126-134. [CrossRef]

46. Hayat, R.; Ali, S.; Amara, U.; Khalid, R.; Ahmed, I. Soil beneficial bacteria and their role in plant growth promotion: A review. Ann. Microbiol. 2010, 60, 579-598. [CrossRef]

47. Straker, C.J.; Mitchell, D.T. The activity and characterization of acid phosphatases in endomycorrhizal fungi of the Ericaceae. New Phytol. 1986, 104, 243-256. [CrossRef]

48. Khan, M.S.; Zaidi, A.; Ahemad, M.; Oves, M.; Wani, P.A. Plant growth promotion by phosphate solubilizing fungi-Current perspective. Arch. Agron. Soil Sci. 2010, 56, 73-98. [CrossRef]

49. Elias, F.; Woyessa, D.; Muleta, D. Phosphate Solubilisation Potential of Rhizosphere Fungi Isolated from Plants in Jimma Zone, Southwest Ethiopia. Int. J. Microbiol. 2016, 2016, 5472601. [CrossRef] [PubMed]

50. Daly, D.H.; Velivelli, S.L.S.; Prestwich, B.D. The Role of Soil Microbes in Crop Biofortification. In Agriculturally Important Microbes for Sustainable Agriculture; Meena, V., Mishra, P., Bisht, J., Pattanayak, A., Eds.; Springer: Singapore, 2017. [CrossRef]

51. Khan, A.; Singh, J.; Upadhayay, V.K.; Singh, A.V.; Shah, S. Microbial Biofortification: A Green Technology Through Plant Growth Promoting Microorganisms. In Sustainable Green Technologies for Environmental Management; Shah, S., Venkatramanan, V., Prasad, R., Eds.; Springer: Singapore, 2019. [CrossRef]

52. Bhatti, T.M.; Yawar, W. Bacterial solubilization of phosphorus from phosphate rock containing sulfur-mud. Hydrometallurgy 2010, 103, 54-59. [CrossRef]

53. Radzki, W.; Gutierrez Manero, F.J.; Algar, E.; Lucas Garcıa, J.A.; Garcı-Villaraco, A.; Solano, B.R. Bacterial siderophores efficiently provide iron to iron-starved tomato plants in hydroponics culture. Antonie Van Leeuwenhoek 2013, 104, 321-330. [CrossRef] 
54. Sharma, A.; Johri, B.N. Growth promoting influence of siderophore-producing Pseudomonas strains GRP3A and PRS9 in maize (Zea mays L.) under iron limiting conditions. Microbiol. Res. 2003, 158, 243-248. [CrossRef]

55. Yehuda, Z.; Shenker, M.; Romheld, V.; Marschner, H.; Hadar, Y.; Chen, Y. The Role of Ligand Exchange in the uptake of Iron from Microbial Siderophores by Cramineous Plants. Plant Physiol. 1996, 112, 1273-1280. [CrossRef]

56. Nadeem, S.M.; Zahir, Z.A.; Naveed, M.; Ashghar, H.N.; Arshad, M. Rhizobacteria capable of producing ACC deaminase may mitigate salt stress in wheat. Soil Biol. Biochem. 2010, 74, 533-542. [CrossRef]

57. Meena, V.S.; Maurya, B.R.; Prakash, J. Does a rhizospheric microorganism enhance $\mathrm{K}^{+}$availability in agricultural soils? Microbiol. Res. 2014, 169, 337-347. [CrossRef]

58. Cardoso, I.M.; Kuyper, T.W. Mycorrhizas and tropical soil fertility. Agric. Ecosyst. Environ. 2006, 116, 72-84. [CrossRef]

59. Jalili, F.; Khavazi, K.; Pazira, E.; Nejati, A.; Rahmani, H.A.; Sadaghiani, H.R.; Miransari, M. Isolation and characterization of ACC deaminase-producing fluorescent pseudomonads, to alleviate salinity stress on canola (Brassica napus L.) growth. J. Plant Physiol. 2008, 166, 667-674. [CrossRef] [PubMed]

60. Ali, S.; Charles, T.C.; Glick, B.R. Amelioration of high salinity stress damage by plant growth promoting bacterial endophytes that contain ACC deaminase. Plant Physiol. Biochem. 2014, 80, 160-167. [CrossRef] [PubMed]

61. Pérez-Montano, F.; Alías-Villegas, C.; Bellogín, R.A.; del Cerro, P.; Espuny, M.R.; Jiménez-Guerrero, I.; López-Baena, F.J.; Ollero, F.J.; Cubo, T. Plant growth promotion in cereal and leguminous agricultural important plants: From microorganism capacities to crop production. Microbiol. Res. 2014, 169, 325-336. [CrossRef] [PubMed]

62. Jha, C.K.; Saraf, M. Plant growth promoting Rhizobacteria (PGPR): A review. E3 J. Agric. Res. Dev. 2015, 5, 0108-0119.

63. Dodd, I.C.; Ruiz-Lozano, J.M. Microbial Enhancement of crop resource use efficiency. Curr. Opin. Biotechnol. 2012, 23, 236-242. [CrossRef]

64. Hassen, A.I.; Bopape, F.L.; Sanger, L.K. Microbial Inoculants as Agents of Growth Promotion and Abiotic Stress Tolerance in Plants. In Microbial Inoculants in Sustainable Agricultural Productivity; Singh, D., Singh, H., Prabha, R., Eds.; Springer: New Delhi, India, 2016; pp. 23-36. [CrossRef]

65. Recep, K.; Fikrettin, S.; Erkol, D.; Cafer, E. Biological control of the potato dry rot caused by Fusarium species using PGPR strains. Biol. Control 2009, 50, 194-198. [CrossRef]

66. Moussa, T.A.A.; Almaghrabi, O.A.; Abdel-Moneim, T.S. Biological control of the wheat root rot caused by Fusarium graminearum using some PGPR strains in Saudi Arabia. Ann. Appl. Biol. 2013, 163, 72-81. [CrossRef]

67. Díaz, A.; Smith, A.; Mesa, P.; Zapata, J.; Caviedes, D.; Cotes, A.M. Control of Fusarium Wilt in Cape Gooseberry by Trichoderma koningiopsis and PGPR; Pertot, I., Elad, Y., Barka, E.A., Clément, C., Eds.; Working Group Biological Control of Fungal and Bacterial Plant Pathogens; IOBC Bulletin: Dijon, France, 2013; Volume 86, pp. 89-94.

68. Vanitha, S.; Ramjegathesh, R. Bio Control Potential of Pseudomonas fluorescens against Coleus Root Rot Disease. J. Plant Pathol. Microb. 2014, 5, 216. [CrossRef]

69. Dixit, R.; Agrawal, L.; Gupta, S.; Kumar, M.; Yadav, S.; Chauhan, P.S.; Nautiyal, C.S. Southern blight disease of tomato control by 1-aminocyclopropane1-carboxylate (ACC) deaminase producing Paenibacillus lentimorbus B30488. Plant Signal. Behav. 2016, 11, e1113363. [CrossRef]

70. Li, X.L.; George, E.; Marschner, H. Extension of the phosphorus depletion zone in VA-mycorrhizal white clover in a calcareous soil. Plant Soil 1991, 136, 41-48. [CrossRef]

71. Wu, Y.; Lin, H.; Lin, Y.; Shi, J.; Xue, S.; Hung, Y.; Chen, Y.; Wang, H. Effects of biocontrol bacteria Bacillus amyloliquefaciens LY-1 culture broth on quality attributes and storability of harvested litchi fruit. Postharvest Biol. Technol. 2017, 132, 81-87. [CrossRef]

72. Zhao, D.; Zhao, H.; Zhao, D.; Zhua, X.; Wang, Y.; Duan, Y.; Xuan, Y.; Chen, L. Isolation and identification of bacteria from rhizosphere soil and their effect on plant growth promotion and root-knot nematode disease. Biol. Control 2018, 119, 12-19. [CrossRef]

73. de Vrieze, M.; Germanier, F.; Vuille, N.; Weisskopf, L. Combining Different Potato-Associated Pseudomonas Strains for Improved Biocontrol of Phytophthora infestans. Front. Microbiol. 2018, 9, 2573. [CrossRef] [PubMed] 
74. Berendsen, R.L.; Vismans, G.; Yu, K.; Song, Y.; de Jonge, R.; Burgman, W.P.; Burmølle, M.; Herschend, J.; Bakker, P.A.; Pieterse, C.M. Disease-induced assemblage of a plant-beneficial bacterial consortium. ISME J. 2018, 12, 1496-1507. [CrossRef] [PubMed]

75. Gadhave, K.R.; Hourston, J.E.; Gange, A.C. Developing Soil Microbial Inoculants for Pest Management: Can One Have Too Much of a Good Thing? J. Chem. Ecol. 2016, 42, 348-356. [CrossRef]

76. Schausberger, P.; Peneder, S.; Juerschik, S.; Hoffmann, D. Mycorrhiza changes plant volatiles to attract spidermite enemies. Funct. Ecol. 2012, 26, 441-449. [CrossRef]

77. Pangesti, N.; Weldegergis, B.T.; Langendorf, B.; van Loon, J.J.; Dicke, M.; Pineda, A. Rhizobacterial colonization of roots modulates plant volatile emission and enhances the attraction of a parasitoid wasp. to host-infested plants. Oecologia 2015, 178, 1169-1180. [CrossRef]

78. Herman, M.A.B.; Nault, B.A.; Smart, C.D. Effects of plant growth-promoting rhizobacteria on bell pepper production and green peach aphid infestations in New York. Crop Prot. 2008, 27, 996-1002. [CrossRef]

79. Velivelli, S.L.S.; Sessitsch, A.; Prestwich, B.D. The Role of Microbial Inoculants in Integrated Crop Management Systems. Potato Res. 2014, 57, 291-309. [CrossRef]

80. Karthiba, L.; Saveetha, K.; Suresh, S.; Raguchander, T.; Saravanakumar, D.; Samiyappan, R. PGPR and entomopathogenic fungus bioformulation for the synchronous management of leaffolder pest and sheath blight disease of rice. Pest. Manag. Sci. 2010, 66, 555-564. [CrossRef]

81. Bano, A.; Muqarab, R. Plant defence induced by PGPR against Spodoptera litura in tomato (Solanum lycopersicum L.). Plant Biol. 2017, 19, 406-412. [CrossRef] [PubMed]

82. Xiang, N.; Lawrence, K.S.; Kloepper, J.W.; Donald, P.A.; McInroy, J.A. Biological control of Heterodera glycines by spore-forming plant growth-promoting rhizobacteria (PGPR) on soybean. PLoS ONE 2017, 12, e0181201. [CrossRef] [PubMed]

83. Viljoen, J.F.; Labuschagne, N.; Fourie, H.; Sikora, R.A. Biological control of the root-knot nematode Meloidogyne incognita on tomatoes and carrots by plant growth-promoting rhizobacteria. Trop Plant Pathol. 2019, 44, 284-291. [CrossRef]

84. Frankowski, J.; Lorito, M.; Scala, F.; Schmid, R.; Berg, G.; Bahl, H. Purification and properties of two chitinolytic enzymes of Serratia plymuthica HRO-C48. Arch. Microbiol. 2001, 176, 421-426. [CrossRef]

85. Kim, Y.C.; Jung, H.; Kim, K.Y.; Park, S.K. An effective biocontrol bioformulation against Phytophthora blight of pepper using growth mixtures of combined chitinolytic bacteria under different field conditions. Eur. J. Plant Pathol. 2008, 120, 373-382. [CrossRef]

86. Singh, P.P.; Shin, Y.C.; Park, C.S.; Chung, Y.R. Biological control of Fusarium wilt of cucumber by chitinolytic bacteria. Phytopathology 1999, 89, 92-99. [CrossRef]

87. Leeman, M.; Ouder, F.M.D.; Pelt, J.A.V.; Dirk, F.P.M.; Steij, H.; Bakker, P.A.; Schippers, B. Iron availability affects induction of systemic resistance to Fusarium wilt of radishes by Pseudomonas fluorescens. Phytopathology 1996, 86, 149-155. [CrossRef]

88. Buysens, S.; Heungens, K.; Poppe, J.; Höftee, M. Involvement of pyochelin and pyoverdin in suppression of Pythium-induced damping-off of tomato by Pseudomonas aeruginosa 7NSK2. Appl. Environ. Microbiol. 1996, 62, 865-871. [CrossRef]

89. Khandelwal, S.R.; Manwar, A.V.; Chaudhari, B.L.; Chincholkar, S.B. Siderophorogenic bradyrhizobia boost yield of soybean. Appl. Biochem. Biotechnol. 2002, 102, 155-168. [CrossRef]

90. Toklikishvili, N.; Dandurishvili, M.; Tediashvili, N.; Lurie, G.S.; Szegedi, E.; Glick, B.R.; Chermin, L.N. Inhibitory effect of ACC deaminase-producing bacteria on crown gall formation in tomato plants infected by Agrobacterium tumefaciens or A. vitis. Plant Pathol. 2010, 59, 1023-1030. [CrossRef]

91. Niu, D.D.; Zheng, Y.; Zheng, L.; Jiang, C.H.; Zhou, D.M.; Guo, J.H. Application of PSX biocontrol preparation confers root-knot nematode management and increased fruit quality in tomato under field conditions. Biocontrol. Sci. Technol. 2016, 26, 174-180. [CrossRef]

92. Santhanam, S.; Luu, V.T.; Weinhold, A.; Goldberg, J.; Oh, Y.; Baldwin, I.T. Native root-associated bacteria rescue a plant from a sudden-wilt disease that emerged during continuous cropping. Proc. Natl. Acad. Sci. USA 2015, 112, E5013-E5020. [CrossRef] [PubMed]

93. Hunziker, L.; Bönisch, D.; Groenhagen, U.; Bailly, A.; Schulz, S.; Weisskopf, L. Pseudomonas strains naturally associated with potato plants produce volatiles with high potential for inhibition of Phytophthora infestans. Appl. Environ. Microbiol. 2015, 81, 821-830. [CrossRef] [PubMed] 
94. Guyer, A.; de Vrieze, M.; Bönisch, D.; Gloor, R.; Musa, T.; Bodenhausen, N.; Bailly, A.; Weisskopf, L. The Anti-Phytophthora Effect of Selected Potato-Associated Pseudomonas Strains: From the Laboratory to the Field. Front. Microbiol. 2015, 6, 1309. [CrossRef] [PubMed]

95. New, P.B.; Kerr, A. Biological Control of Crown Gall: Field Measurements and Glasshouse Experiments. J. Appl. Buct. 1972, 35, 279-287. [CrossRef]

96. Allizadeh, H.; Behboudi, K.; Masoud, A.; Javan-Nikkhah, M.; Zamioudis, C.; Corné, M.J.P.; Bakker, A.H.M. Induced systemic resistance in cucumber and Arabidopsis thaliana by the combination of Trichoderma harzianum Tr6 and Pseudomonas sp. Ps14. Biol. Control 2013, 65, 14-23. [CrossRef]

97. Durgadevi, D.; Srivignesh, S.; Sankaralingam, A. Effect of Consortia Bioformulation of Rhizobacteria on Induction of Systemic Resistance in Tuberose against Peduncle Blight Disease. Int. J. Bio Resour. Stress Manag. 2018, 9, 510-517. [CrossRef]

98. Takishita, Y.; Charron, J.B.; Smith, D.L. Biocontrol Rhizobacterium Pseudomonas sp. 23 S Induces Systemic Resistance in Tomato (Solanum lycopersicum L.) Against Bacterial Canker Clavibacter michiganensis subsp. michiganensis. Front. Microbiol. 2018, 9, 2119. [CrossRef]

99. Kumar, S.; Chauhan, P.S.; Agrawal, L.; Raj, R.; Srivastava, A.; Gupta, S.; Mishra, S.K.; Yadav, S.; Singh, P.C.; Raj, S.K.; et al. Paenibacillus lentimorbus Inoculation Enhances Tobacco Growth and Extenuates the Virulence of Cucumber mosaic virus. PLoS ONE 2016, 11, e0149980. [CrossRef]

100. Schuhegger, R.; Ihring, A.; Gantner, S.; Bahnweg, G.; Knappe, C.; Vogg, G.; Hutzler, P.; Schmid, M.; Breusegem, F.V.; Eberl, L.; et al. Induction of systemic resistance in tomato by N-acyl-L-homoserine lactone-producing rhizosphere bacteria. Plant Cell Environ. 2006, 29, 909-918. [CrossRef]

101. Baffoni, L.; Gaggia, F.; Dalanaj, N.; Prodi, A.; Nipoti, P.; Pisi, A.; Biavati, B.; Gioia, D.D. Microbial inoculants for the biocontrol of Fusarium spp. in durum wheat. BMC Microbiol. 2015, 15, 242. [CrossRef] [PubMed]

102. Martinuz, A.; Schouten, A.; Menjivar, R.; Sikora, R. Effectiveness of systemic resistance toward Aphis gossypii (Hom., Aphididae) as induced by combined applications of the endophytes Fusarium oxysporum Fo162 and Rhizobium etli G12. Biol. Control 2012, 62, 206-212. [CrossRef]

103. Valenzuela-Soto, J.H.; Estrada-Hernandez, M.G.; Ibarra-Laclette, E.; Delano-Frier, J.P. Inoculation of tomato plants (Solanum lycopersicum) with growth-promoting Bacillus subtilis retards whitefly Bemisia tabaci development. Planta 2010, 231, 397-410. [CrossRef] [PubMed]

104. Srivastava, S.; Bist, V.; Srivastava, S.; Singh, P.C.; Trivedi, P.K.; Asif, M.H.; Chauhan, P.S.; Nautiyal, C.S. Unraveling aspects of Bacillus amyloliquefaciens mediated enhanced production of rice under biotic stress of Rhizoctonia solani. Front. Plant Sci. 2016, 7, 587. [CrossRef] [PubMed]

105. Collins, M.; Knutti, R.; Arblaster, J.; Dufresne, L.; Fichefet, T.; Friedlingstein, P.; Gao, X.; Gutowski, W.J.; Johns, T.; Krinner, G.; et al. Long-term Climate Change: Projections, Commitments and Irreversibility. In Climate Change 2013: The Physical Science Basis. Contribution of Working Group I to the Fifth Assessment Report of the Intergovernmental Panel on Climate Change; Stocker, T.F., Qin, D., Plattner, G.-K., Tignor, M., Allen, S.K., Boschung, J., Nauels, A., Xia, Y., Bex, V., Midgley, P.M., Eds.; Cambridge University Press: New York, NY, USA, 2013; pp. 1029-1136.

106. Xu, D.Y.; Kang, X.W.; Zhuang, D.F.; Pan, J.J. Multi-scale quantitative assessment of the relative roles of climate change and human activities in desertification-A case study of the Ordos Plateau, China. J. Arid Environ. 2010, 74, 498-507. [CrossRef]

107. Tank, N.; Saraf, M. Salinity-resistant plant growth promoting rhizobacteria ameliorates sodium chloride stress on tomato plants. J. Plant Interact. 2010, 5, 51-58. [CrossRef]

108. Rousk, J.; Elyaagubi, F.K.; Jones, D.L.; Godbold, D.L. Bacterial salt tolerance is unrelated to soil salinity across an arid agroecosystem salinity gradient. Soil Biol. Biochem. 2011, 43, 1881-1887. [CrossRef]

109. Egamberdieva, D.; Lugtenberg, B. Use of Plant Growth-Promoting Rhizobacteria to Alleviate Salinity Stress in Plants. In Use of Microbes for the Alleviation of Soil Stresses; Miransari, M., Ed.; Springer Science + Business Media: New York, NY, USA, 2014; pp. 73-96. [CrossRef]

110. Shrivastava, P.; Kumar, R. Soil salinity: A serious environmental issue and plant growth promoting bacteria as one of the tools for its alleviation. Saudi J. Biol. Sci. 2015, 22, 123-131. [CrossRef]

111. Yan, N.; Marschner, P.; Cao, W.; Zuo, C.; Qin, W. Influence of salinity and water content on soil microorganisms. Int. Soil Water Conserv. Res. 2015, 3, 316-323. [CrossRef]

112. Chen, L.; Liu, Y.; Wu, G.; Njeri, K.V.; Shen, O.; Zhang, N.; Zhang, R. Induced maize salt tolerance by rhizosphere inoculation of Bacillus amyloliquefaciens SQR9. Physiol. Plant 2016, 158, 34-44. [CrossRef] 
113. Subramanian, P.; Mageswari, A.; Kim, K.; Lee, Y.; Sa, T. Psychrotolerant endophytic Pseudomonas sp. strains OB155 and OS261 induced chilling resistance in tomato plants (Solanum lycopersicum mill.) by activation of their antioxidant capacity. Mol. Plant Microbe Interact. 2015, 28, 1073-1081. [CrossRef] [PubMed]

114. Tiwari, S.; Lata, C.; Chauhan, S.P.; Chandra Shekhar Nautiyal, C.P. Pseudomonas putida attunes morphophysiological, biochemical and molecular responses in Cicer arietinum L. during drought stress and recovery. Plant Physiol. Biochem. 2016, 99, 108-117. [CrossRef] [PubMed]

115. Wang, Q.; Dodd, I.C.; Belimov, A.A.; Jiang, F. Rhizosphere bacteria containing 1-aminocyclopropane-1-carboxylate deaminase increase growth and photosynthesis of pea plants under salt stress by limiting $\mathrm{Na}^{+}$accumulation. Funct. Plant Biol. 2016, 43, 161-172. [CrossRef] [PubMed]

116. Bhartirt, N.; Pandey, S.S.; Barnawal, D.; Patel, V.K.; Kalra, A. Plant growth promoting rhizobacteria Dietzia natronolimnaea modulates the expression of stress responsive genes providing protection of wheat from salinity stress. Sci. Rep. 2016, 6, 34768. [CrossRef]

117. Subramanian, S.; Ricci, E.; Souleimanov, A.; Smith, D.L. A proteomic approach to lip-chitooligosaccharide and thuricin 17 effects on soybean germination under salt stress. PLoS ONE 2016, 11, e0160660. [CrossRef] [PubMed]

118. Rolli, E.; Marasco, R.; Vigani, G.; Ettoumi, B.; Mapelli, F.; Deangelis, M.L.; Gandolfi, C.; Casati, F.; Previtali, F.; Gerbino, R.; et al. Improved plant resistance to drought is promoted by the root-associated microbiome as a water stress-dependent trait. Environ. Microbiol. 2015, 17, 316-331. [CrossRef]

119. Molina-Romero, D.; Baez, A.; Quintero-Hernández, V.; Castañeda-Lucio, M.; Fuentes-Ramírez, L.E.; Bustillos-Cristales, M.D.R.; Rodríguez-Andrade, O.; Morales-García, Y.E.; Munive, A.; Muñoz-Rojas, J. Compatible bacterial mixture, tolerant to desiccation, improves maize plant growth. PLoS ONE 2017, 12, e0187913. [CrossRef]

120. Akhtar, S.S.; Amby, D.B.; Hegelund, J.N.; Fimognari, L.; Großkinsky, D.K.; Westergaard, J.C.; Muller, R.; Melba, L.; Liu, F.; Roitsch, T. Bacillus licheniformis FMCH001 increases water use efficiency via growth stimulation in both normal and drought conditions. Front. Plant Sci. 2020, 11, 297. [CrossRef]

121. Yang, A.; Akhtar, S.S.; Fu, Q.; Naveed, M.; Iqbal, S.; Roitsch, T.; Jacobsen, S.E. Burkholderia Phytofirmans PsJN Stimulate Growth and Yield of Quinoa under Salinity Stress. Plants 2020, 9, 672. [CrossRef]

122. Zahran, H.H. Rhizobium-Legume Symbiosis and Nitrogen Fixation under Severe Conditions and in an Arid Climate. Microbiol. Mol. Biol. Rev. 1999, 63, 968-989. [CrossRef]

123. Etesami,H.; Mirseyedhosseini, H.; Alikhani, H.A. Bacterial biosynthesis of 1-aminocyclopropane-1-caboxylate (ACC) deaminase, a useful trait to elongation and endophytic colonization of the roots of rice under constant flooded conditions. Physiol. Mol. Biol. Plants 2014, 20, 425-434. [CrossRef] [PubMed]

124. Kang, S.M.; Khan, A.L.; Waqs, M.; You, Y.H.; Hamayun, M.; Joo, G.; Shahzad, R.; Choi, K.; Lee, I.J. Gibberellin-producing Serratia nematodiphila PEJ1011 ameliorates low temperature stress in Capsicum annuum L. Eur. J. Soil Biol. 2015, 68, 85-93. [CrossRef]

125. Fernandez, O.; Theocharis, A.; Bordiec, S.; Feil, R.; Jacquens, L.; Clément, C.; Fontaine, F.; Barka, E.A. Burkholderia phytofirmans PsJN Acclimates Grapevine to Cold by Modulating Carbohydrate Metabolism. Mol. Plant Microbe Interact. 2012, 25, 496-504. [CrossRef]

126. Barnawal, D.; Bharti, N.; Maji, D.; Chanotiya, C.S.; Kalra, A. 1-Aminocyclopropane-1-carboxylic acid (ACC) deaminase containing rhizobacteria protect Ocimum sanctum plants during water logging stress via reduced ethylene generation. Plant Physiol. Biochem. 2012, 58, 227-235. [CrossRef] [PubMed]

127. Bano, A.; Fatima, M. Salt tolerance in Zea mays (L.) following inoculation with Rhizobium and Pseudomonas. Biol. Fertil. Soils 2009, 45, 405-413. [CrossRef]

128. Karthikeyan, B.; Joe, M.M.; Islam, M.D.R.; Sa, T. ACC deaminase containing diazotrophic endophytic bacteria ameliorate salt stress in Catharanthus roseus through reduced ethylene levels and induction of antioxidative defense systems. Symbiosis 2012, 56, 77-86. [CrossRef]

129. Mallick, I.; Bhattacharyya, C.; Mukherji, S.; Sarkar, S.C.; Mukhopadhyay, U.K.; Ghosh, A. Effective rhizoinoculation and biofilm formation by arsenic immobilizing halophilic plant growth promoting bacteria (PGPB) isolated from mangrove rhizosphere: A step towards arsenic rhizoremediation. Sci. Total Environ. 2018, 610, 1239-1250. [CrossRef] [PubMed]

130. Tripathi, P.; Singh, P.C.; Mishra, A.; Srivastava, S.; Chauhan, R.; Awasthi, S.; Mishra, S.; Dwivedi, S.; Tripathi, P.; Kalra, A.; et al. Arsenic tolerant Trichoderma sp. reduces arsenic induced stress in chickpea (Cicer arietinum). Environ. Pollut. 2017, 223, 137-145. [CrossRef] 
131. Sánchez-Yáñez, J.M.; Alonso-Bravo, J.N.; Dasgupta-Schuber, N.; Márquez-Benavides, L. Bioremediation of soil contaminated by waste motor oil in 55,000 and 65,000 and phytoremediation by Sorghum bicolor inoculated with Burkholderia cepacia and Penicillium chrysogenum. J. Selva Andina Biosph. 2015, 3, 86-94.

132. Sarkar, J.; Chakraborty, B.; Chakraborty, U. Plant Growth Promoting Rhizobacteria Protect Wheat Plants Against Temperature Stress Through Antioxidant Signalling and Reducing Chloroplast and Membrane Injury. J. Plant Growth Regul. 2018, 37, 1396-1412. [CrossRef]

133. Islam, F.; Yasmeen, T.; Ali, O.; Ali, S.; Arif, S.M.; Sabir Hussain, S.; Rizv, H. Influence of Pseudomonas aeruginosa as PGPR on oxidative stress tolerance in wheat under Zn stress. Ecotoxicol. Environ. Saf. 2014, 104, 285-293. [CrossRef] [PubMed]

134. Berninger, T.; Lopez, O.G.; Bejarano, A.; Preininger, C.; Sessitsch, A. Maintenance and assessment of cell viability in formulation of non-sporulating bacterial inoculants. Microb. Biotechnol. 2018, 11, 277-301. [CrossRef]

135. Mehnaz, S. An Overview of Globally Available Bioformulations. In Bioformulations: For Sustainable Agriculture; Arora, N., Mehnaz, S., Balestrini, R., Eds.; Springer: New Delhi, India, 2016; pp. 267-281. [CrossRef]

136. Arthur, S.; Dara, S.K. Microbial biopesticides for invertebrate pests and their markets in the United States. J. Invertebr. Pathol. 2018, 165, 13-21. [CrossRef]

137. Babalola, O.O.; Glick, B.R. Indigenous African agriculture and plant associated microbes: Current practice and future transgenic prospects. Sci. Res. Essays 2012, 7, 2431-2439.

138. Aremu, B.R.; Alori, E.T.; Kutu, R.F.; Babalola, O.O. Potentials of Microbial Inoculants in Soil Productivity: An Outlook on African Legumes. In Microorganisms for Green Revolution. Microorganisms for Sustainability; Panpatte, D., Jhala, Y., Vyas, R., Shelat, H., Eds.; Springer: Singapore, 2017; Volume 6. [CrossRef]

139. Souleimanov, A.; Prithiviraj, B.; Smith, D. The major Nod factor of Bradyrhizobium japonicum promotes early growth of soybean and corn. J. Exp. Bot. 2002, 53, 1929-1934. [CrossRef] [PubMed]

140. Gray, E.J.; Lee, K.D.; Souleimanov, A.M.; Di Falco, M.R.; Zhou, X.; Ly, A.; Charles, T.C.; Driscoll, B.T.; Smith, D.L. A novel bacteriocin, thuricin 17, produced by plant growth promoting rhizobacteria strain Bacillus thuringiensis NEB17: Isolation and classification. J. Appl. Microbiol. 2006, 100, 545-554. [CrossRef]

141. Subramanian, S.; Souleimanov, A.; Smith, D.L. Proteomic Studies on the Effects of Lipochitooligosaccharide and Thuricin 17 under Unstressed and Salt Stressed Conditions in Arabidopsis thaliana. Front. Plant Sci. 2016, 7, 1314. [CrossRef]

142. Arunachalam, S.; Schwinghamer, T.; Dutilleul, P.; Smith, D.L. Multi-Year Effects of Biochar, Lipo-Chitooligosaccharide, Thuricin 17, and Experimental Bio-Fertilizer for Switchgrass. Agron. J. 2018, 110, 77-84. [CrossRef]

143. Navarro, M.O.P.; Piva, A.C.M.; Simionato, A.S.; Spago, F.R.; Modolon, F.; Emiliano, J.; Azul, A.M.; Chryssafidis, A.L.; Andrade, G. Bioactive Compounds Produced by Biocontrol Agents Driving Plant Health. In Microbiome in Plant Health and Disease; Kumar, V., Prasad, R., Kumar, M., Choudhary, D., Eds.; Springer: Singapore, 2019; pp. 337-374. [CrossRef]

144. Prudent, M.; Salon, C.; Souleimanov, S.A.; Emery, R.J.N.; Smith, D.L. Soybean is less impacted by water stress using Bradyrhizobium japonicum and thuricin-17 from Bacillus thuringiensis. Agron. Sustain. Dev. 2015, 35, 749-757. [CrossRef]

145. Schwinghamer, T.; Souleimanov, A.; Dutilleul, P.; Smith, D.L. Supplementation with solutions of lipo-chitooligosaccharide $\operatorname{Nod~Bj~V~(C18:1,~MeFuc)~and~thuricin~} 17$ regulates leaf arrangement, biomass, and root development of canola (Brassica napus [L.]). Plant Growth Regul. 2015, 78, 31-41. [CrossRef]

146. Yuan, L.; Li, Y.; Wang, Y.; Zhang, X.; Xu, Y. Optimization of critical medium components using response surface methodology for phenazine-1-carboxylic acid production by Pseudomonas sp. M-18Q. J. Biosci. Bioeng. 2008, 3, 232-237. [CrossRef] [PubMed]

147. Xu, S.; Pan, X.; Luo, J.; Wu, J.; Zhou, Z.; Liang, X.; He, Y.; Zhou, M. Effects of phenazine-1-carboxylic acid on the biology of the plant-pathogenic bacterium Xanthomonas oryzae pv. Oryzae. Pestic. Biochem. Physiol. 2015, 117, 39-46. [CrossRef] [PubMed]

148. Chen, C.; Mciver, J.; Yang, Y.; Bai, Y.; Schultz, B.; Mciver, A. Foliar application of lipochitooligosaccharides (Nod factors) to tomato (Lycopersicon esculentum) enhances flowering and fruit production. Can. J. Plant Sci. 2007, 87, 365-372. [CrossRef]

149. Duke, S.O.; Lydon, J. Herbicides from Natural Compounds. Weed Technol. 1987, 1, 122-128. [CrossRef] 
150. Zhang, Z.K.; Huber, D.J.; Qu, H.X.; Yun, Z.; Wang, H.; Huang, Z.H.; Huang, H.; Jiang, Y.M. Enzymatic browning and antioxidant activities in harvested litchi fruit as influenced by apple polyphenols. Food Chem. 2015, 171, 191-199. [CrossRef]

151. Shanmugaiah, V.; Mathivanan, N.; Varghese, B. Purification, crystal structure and antimicrobial activity of phenazine-1-carboxamide produced by a growth-promoting biocontrol bacterium, Pseudomonas aeruginosa MML2212. J. Appl. Microbiol. 2010, 108, 703-711. [CrossRef]

152. Huang, H.; Sun, L.; Bi, K.; Zhong, G.; Hu, M. The effect of phenazine-1-carboxylic acid on the morphological, physiological, and molecular characteristics of Phellinus noxius. Molecules 2016, 21, 613. [CrossRef]

153. Puopolo, G.; Masi, M.; Raio, A.; Andolfi, A.; Zoina, A.; Cimmino, A.; Evidente, A. Insights on the susceptibility of plant pathogenic fungi to phenazine-1-carboxylic acid and its chemical derivatives. Nat. Prod. Res. 2013, 27, 956-966. [CrossRef]

154. Gheorghe, I.; Popa, M.; Marutescu, L.; Saviuc, C.; Lazar, V.; Chifiriuc, M.C. Lessons from interregn communication for development of novel, ecofriendly pesticides. In New Pesticides and Soil Sensors; Grumezescu, A.M., Ed.; Academic Press: London, UK, 2017; pp. 1-46. [CrossRef]

155. Rane, M.R.; Sarode, P.D.; Chaudhari, B.L.; Chincholkar, S.B. Exploring antagonistic metabolites of established biocontrol agent of marine origin. Appl. Biochem. Biotechnol. 2008, 151, 665-675. [CrossRef]

156. Kare, E.; Arora, N.K. Dual activity of pyocyanin from Pseudomonas aeruginosa-Antibiotic against phytopathogen and signal molecule for biofilm development by rhizobia. Can. J. Microbiol. 2011, 57, 708-713. [CrossRef]

157. Jung, B.K.; Hong, S.J.; Park, G.S.; Kim, M.C.; Shin, J.H. Isolation of Burkholderia cepacia JBK9 with plant growth-promoting activity while producing pyrrolnitrin antagonistic to plant fungal diseases. Appl. Biol. Chem. 2018, 61, 173-180. [CrossRef]

158. Okada, A.; Banno, S.; Ichiishi, A.; Kimura, M.; Yamaguchi, I.; Fujimura, M. Pyrrolnitrin interferes with osmotic signal transduction in Neurospora crassa. J. Pestic. Sci. 2005, 30, 378-383. [CrossRef]

159. Han, J.W.; Kim, J.D.; Lee, J.M.; Ham, J.H.; Lee, D.; Kim, B.S. Structural elucidation and antimicrobial activity of new phencomycin derivatives isolated from Burkholderia glumae strain 411gr6. J. Antibiot. 2014, 67, 721. [CrossRef]

160. Deng, P.; Foxfire, A.; Xu, J.; Baird, S.M.; Jia, J.; Delgado, K.H.; Shin, R.; Smith, L.; Lu, S.E. Siderophore product ornibactin is required for the bactericidal activity of Burkholderia contaminans MS14. Appl. Environ. Microbiol. 2017, 83, e00051-17. [CrossRef]

161. Ye, Y.; Li, Q.; Fu, G.; Yuan, G.; Miao, J.; Lin, W. Identification of antifungal substance (Iturin A2) produced by Bacillus subtilis B47 and its effect on southern corn leaf blight. J. Integr. Agric. 2012, 11, 90-99. [CrossRef]

162. Deravel, J.; Lemière, S.; Coutte, F.; Krier, F.; Hese, N.V.; Béchet, M.; Sourdeau, N.; Höfte, M.; Leprêtre, A.; Jacques, P. Mycosubtilin and surfactin are efficient, low ecotoxicity molecules for the biocontrol of lettuce downy mildew. Appl. Microbiol. Biotechnol. 2014, 98, 6255-6264. [CrossRef]

163. Isaac, B.G.; Ayer, S.W.; Elliott, R.C.; Stonard, R.J. Herboxidiene: A potent phytotoxic polyketide from Streptomyces sp. A7847. J. Org. Chem. 1992, 57, 7220-7226. [CrossRef]

164. Saxena, S.; Pandey, A.K. Microbial metabolites as eco-friendly agrochemicals for the next millennium. Appl. Microbiol. Biotechnol. 2001, 55, 395-403. [CrossRef]

165. Tanaka, Y.; Omura, S. Agroactive compounds of microbial origin. Annu. Rev. Microbiol. 1993, 47, 57-87. [CrossRef]

(C) 2020 by the authors. Licensee MDPI, Basel, Switzerland. This article is an open access article distributed under the terms and conditions of the Creative Commons Attribution (CC BY) license (http://creativecommons.org/licenses/by/4.0/). 